This item was submitted to Loughborough's Research Repository by the author.

Items in Figshare are protected by copyright, with all rights reserved, unless otherwise indicated.

\title{
A briefing on the UK's choice of trade arrangements outside of the EU
}

PLEASE CITE THE PUBLISHED VERSION

\section{PUBLISHER}

ESRC UK in a Changing Europe

VERSION

VoR (Version of Record)

\section{PUBLISHER STATEMENT}

This work is made available according to the conditions of the Creative Commons Attribution-NonCommercialNoDerivatives 4.0 International (CC BY-NC-ND 4.0) licence. Full details of this licence are available at: https://creativecommons.org/licenses/by-nc-nd/4.0/

\section{LICENCE}

CC BY-NC-ND 4.0

\section{REPOSITORY RECORD}

Douch, Mustapha, T. Huw Edwards, and Alistair Milne. 2019. "A Briefing on the Uk's Choice of Trade Arrangements Outside of the EU”. figshare. https://hdl.handle.net/2134/26036. 


\title{
A briefing on the UK's choice of trade arrangements outside of the EU
}

\author{
Mustupha Douch ${ }^{1}$, Huw Edwards ${ }^{2}$ and Alistair Milne ${ }^{3}$
}

School of Economics and Business, Loughborough University

July $12^{\text {th }} 2017$

Briefing notes based on public domain materials and a Loughborough conference International Trade Arrangements after Brexit: Establishing the Facts, Dec $9^{\text {th }} 2016$.

"To mourn a mischief that is past and gone is the next way to draw new mischief on."

Othello, Act I, Scene III

This paper and the associated conference were financed by a grant from the ESRC UK in a changing Europe commissioning fund.

This briefing note, prepared by Loughborough University for the ESRC UK in a Changing Europe Initiative, reviews the choices for UK trade arrangements after Brexit. It draws on public domain research by leading UK trade researchers and on the presentations and discussions at a conference, hosted by Loughborough University at our Queen Elizabeth Park, Stratford, London Campus, on Dec 9 $9^{\text {th }}, 2016$. It reviews the economics arguments for free trade, the institutional arrangements that support free-trade and summarises some key statistics about UK external trade. It also argues that the presentation of Brexit as a binary choice between 'soft' (retaining current trade arrangements with the EU) and 'hard' (jettisoning all existing trade arrangements in order to start out afresh) is a dangerous oversimplification. This ignores the realities of negotiation with the EU and other trade partners (the choice is not all or nothing, there is opportunity in negotiation to agree anything across a wide range of potential outcomes). The key policy challenge is choosing between a slow and managed Brexit, extended over a period of five to seven years, ensuring low costs of trade between the UK and the EU and avoiding substantial economic costs, or a rapid Brexit which is likely to reduce GDP by between 5 and 8 percent.

Keywords: brexit, European Customs Union, free trade agreements, non-tariff barriers, tariff barriers, WTO, Single Market

JEL number F13

\footnotetext{
${ }^{1}$ M.Douch@lboro.ac.uk

2 T.H.Edwards@lboro.ac.uk

3 A.K.L.Milne@lboro.ac.uk; corresponding author
} 


\section{Contents}

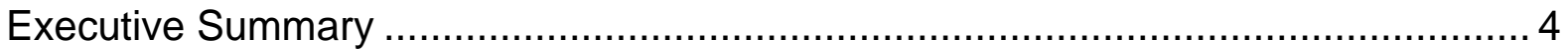

Figure 1: the three choices for future UK trading arrangements ..................... 5

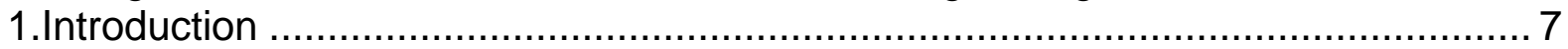

2.The economics of international trade and international trade arrangements: a

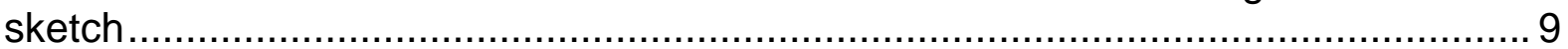

a. The Economic Rationale for Free Trade.................................................... 9

Table 1: trade agreements as a 'prisoner's dilemma' ................................... 10

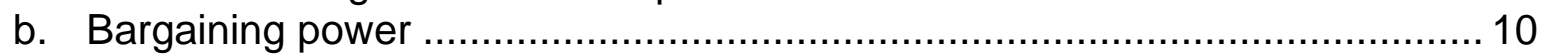

Table 2: UK - EU27 trade as a share of their respective total global trade....... 11

c. Distributional impacts, structural rigidities and special interest lobbying......... 12

d. Dynamic gains from trade ....................................................................... 12

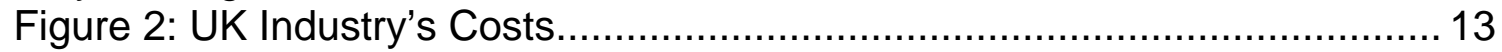

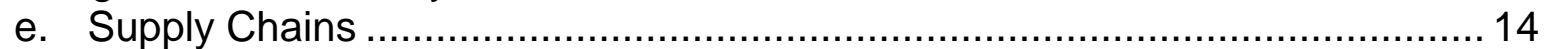

f. Examples of individual industries: motor cars and financial services ............ 16

Table 3: The Trade Contribution of the City .............................................. 17

g. Estimates of Static and Dynamic losses/gains from Brexit...........................20

Table 4: Estimates of the long-run economic impact of Brexit ......................... 21

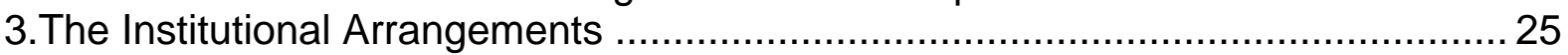

a. Types of Trade Barrier........................................................................ 25

b. Global Trade Agreements: The World Trade Organization .......................... 27

c. Regional Trade Agreements................................................................ 28

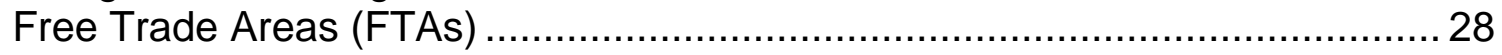

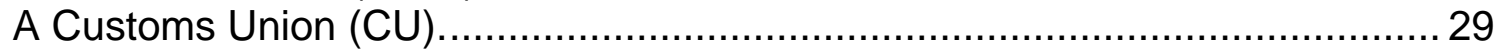

d. Reducing non-tariff barriers through rules on market access ........................29

d. Does the WTO constrain or help UK trade policies after Brexit? ..................... 33

e. A deep and comprehensive EU-UK Free Trade agreement? ........................35

4.Descriptive statistics for UK international trad ............................................... 37

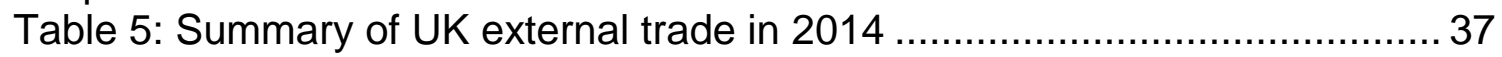

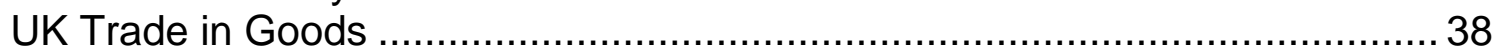

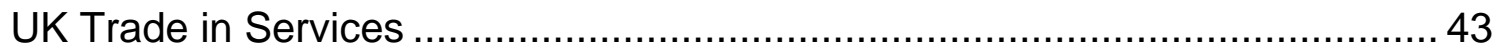

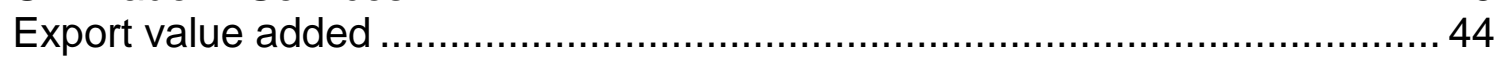

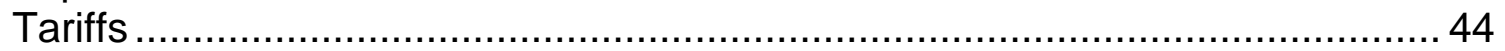

Figures for UK's Services Trade ......................................................... 45

Figures for UK Export Value Added ...................................................... 46

Figures on Historical Aggregate Tariff and 2011 Breakdown ........................... 48

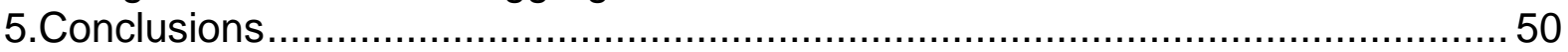

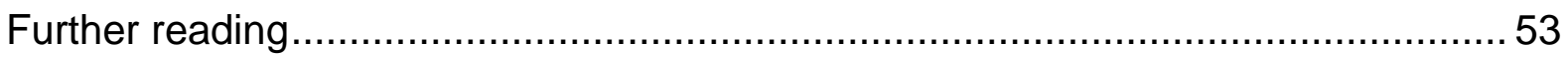




\section{Executive Summary}

This briefing note, prepared by Loughborough University for the ESRC UK in a Changing Europe Initiative, reviews the choices for UK trade arrangements after Brexit. It draws on public domain research by leading UK trade researchers and on the presentations and discussions at a conference, hosted by Loughborough University at our Queen Elizabeth Park, Stratford, London Campus, on Dec 9 ${ }^{\text {th }}, 2017$.

A misleading characterisation. Media and political discussion has characterised Brexit as a binary choice between 'soft' (retaining current trade arrangements with the EU) and 'hard' (jettisoning all existing trade arrangements in order to start out afresh). This is a dangerous oversimplification. It ignores the realities of negotiation with the EU and other trade partners (the choice is not all or nothing, rather we have an opportunity in negotiation to agree anything across a wide range of potential outcomes) and the practical challenge of replacing the large investments in existing trade arrangements by both UK business and UK government.

A better analogy: moving house. Brexit is better seen as the decision of a family to leave an old house in order to move into a new building with better facilities. The family has agreed that the move is worth the costs involved and a final decision has been made to leave. This does not mean that it is necessary to leave the old house today and live in the open air while the new house is being constructed.

Constructing of the new building will take time. A comparatively straightforward step is leaving the EU Customs Union and imposing external tariffs largely based on those that currently apply externally to the EU (this can be done through a 'rectification', transferring all commitments on tariffs agreed by the EU on behalf of the UK back to the UK as a full member of the WTO). This though will still take months and require investment in systems and procedures at the UK frontier.

Non-tariff trade barriers (regulations, products standards) and rules applying to trade in services - I.e. where we currently benefit from deep and comprehensive arrangements of the EU single market - are more difficult, not least because of the requirement for mutual recognition of standards and regulations and a process of dispute resolution when compliance is questioned. Creating the apparatus for monitoring non-tariff barriers for UK trade both with the EU and countries outside the $\mathrm{EU}$, with all the systems and staff required, will take one or two years not months.

\section{Obtaining the 'permissions' for a construction plan will take even longer. We} need to agree new trade arrangements with our EU partners and other countries (we cannot just adopt existing arrangements since that would be staying in the single market and customs union that we plan to leave). This will take several years.

Tariff-arrangements are again more straightforward. Most EU external tariffs are fairly low. The principal exceptions are motor cars and motor car parts and agricultural products. It should be possible to negotiate these two sectors as special 
cases and find a solution of mutual benefit (as we discuss the supply chains of the motor industry cross from the UK/EU several times, in order to avoid substantial cost increases both UK and EU car manufacturers will be insistent on eliminating or substantially reducing these tariffs; UK agriculture likely has to accept tariffs on exports to the EU though 'tariff quota agreements' will need extensive discussion). Agreement should be possible in a year or two.

Negotiation of non-tariff arrangements with the EU is where the greatest problems arise, requiring sector by sector agreement (in financial services, law, architecture, other business services, motor cars, aeronautics, pharmaceuticals, food and drink, to mention just a few prominent sectors). Some institutional arrangement will also be needed to police agreements (one way to speed up final agreement will be to allow the ECJ jurisdiction over UK-EU trade, but some in the UK prefer the creation of a special independent legal authority). Moreover nothing is agreed until everything is agreed. Based on past experience of international trade negotiations - which have never attempted such a deep and comprehensive reworking of trade as must now take place between the EU and the UK - a period of ten years could be needed. With good will and hard work, this may be achievable in about five years.

Cost v. Time. Figure 1 illustrates the possible choices for our future trading arrangements, analysed in the two dimensions of cost and time.

Figure 1: the three choices for future UK trading arrangements

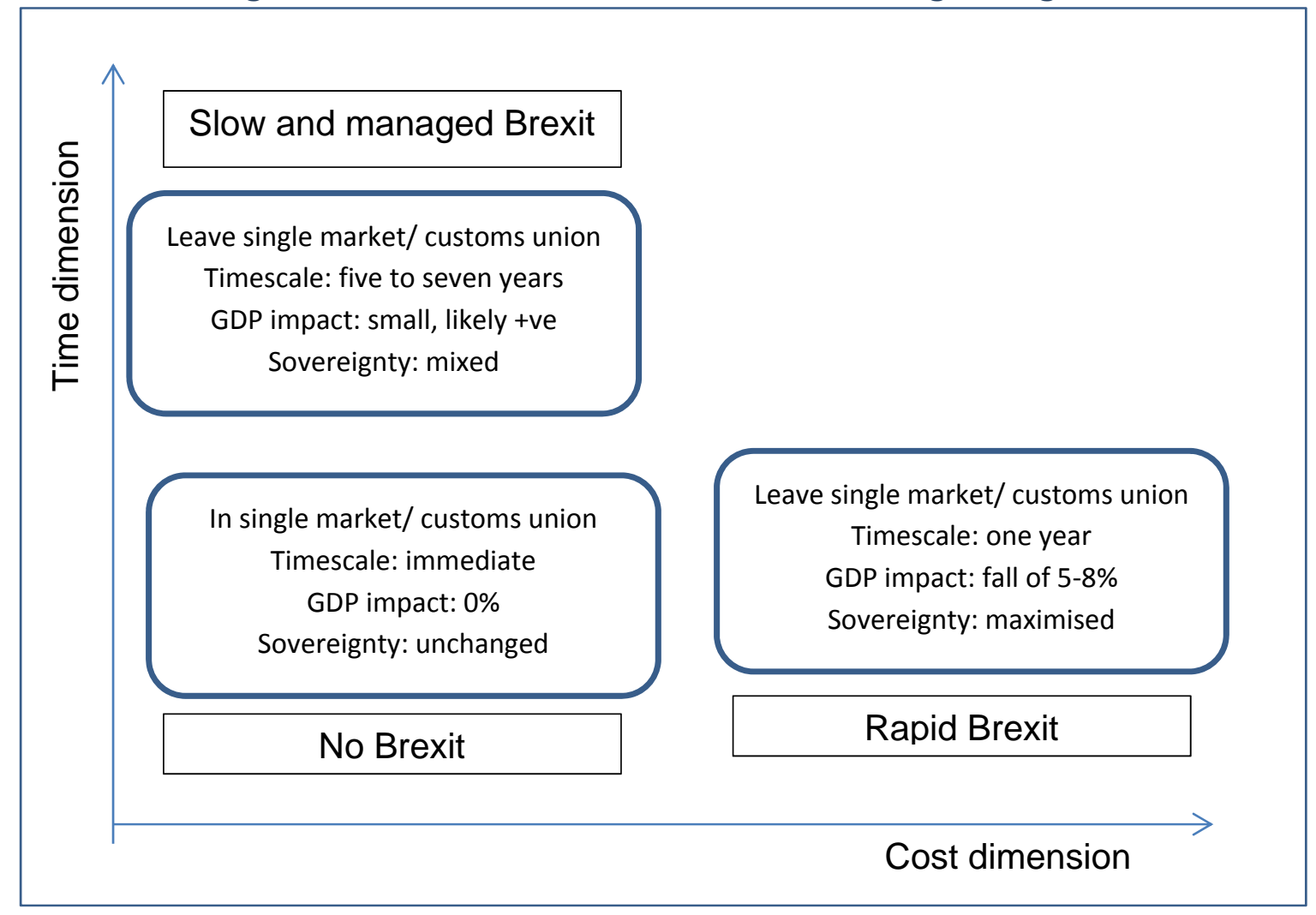


No-one wants a costly Brexit that takes a long time (hence there is no choice presented in the upper-right quadrant of Figure 1). There is though an unavoidable trade-off of cost and time. Doing Brexit quickly makes it unavoidably costly because we are then unable to replace the single market rules with the EU with a new framework to overcome non-tariff barriers to UK-EU trade (the 'rapid Brexit' box on the lower right hand quadrant of the Figure). The research that we review indicates that while the costs of a rapid Brexit are highly uncertain they will involve a loss of UK per capita consumption and GDP of the order of $5-8 \%$.

There are two other possible choices. One is a reversal of the decision to leave on the lower left hand quadrant of Figure 1. The UK would then be able to stay in the Single Market and European Customs Union. This though does not seem politically feasible (while some in the UK continue to call for remaining in the single market and customs union, this would appear to require also continuing to make EU budget contributions and accept full freedom of movement of labour; unless the European Union puts on the table at the beginning of negotiations a substantial concessions on either or both of these issues, such an outcome does not appear compatible with the decision made in the June 2016 referendum).

The final choice, in the upper left quadrant of Figure 1, is a slow and managed Brexit. This will require a transition period of several years, during which the UK will presumably continue to make EU budget contributions and participate in the customs union and single market. Withdrawal first from the customs union and then later from the single market can then take place, with these arrangements replaced by a deep and comprehensive free trade agreements with the EU. While the time involved, five to seven years, will frustrate some supporters of Brexit this is necessary if we are to respect the referendum outcome and leave the European Union while avoiding substantial costs to the UK economy.

The quotation from Othello, on our title page, captures something of what may very well still end in tragedy. No point in mourning a mischief that is past and gone. Both sides of the referendum debate are at fault for not moving on, accepting that a final decision has been made on the UK's membership of the EU, and working together on the protracted task of executing that decision in a carefully managed and least cost fashion, a task which must extend well beyond the latest possible date for the next general election in 2022. 


\section{Introduction}

Trade arrangements are now, for the first time in many years, at the centre of UK policy discussion. As a member of the EU, our trade arrangements have been determined by our membership of both the Single Market and the European Customs Union, effectively outsourcing our trade arrangements to supra-national institutions. Now they are a domestic issue at the heart of economic policy making. These are golden times for trade economists.

Despite this elevation, most discussion of trade arrangements before and since the referendum have been simplistic, moving little beyond largely unsubstantiated campaign claims. We still hear extreme views, either (as many campaigners for leave have asserted) that departure from the European Union presents an opportunity for an immediate and transformative lowering of trade barriers for UK exports and imports; or (as the remain campaign argued) that any alteration of trade arrangements that the UK shares with the EU threatens a substantial decline of both living standards and employment.

Reality is more nuanced than either of these campaigning positions. This note provides a briefing on the issues, providing some key information which should be understand by all those concerned with the future of UK trade arrangements outside of the European Union. It also argues that a key tradeoff in post-EU trade arrangements - that between the speed with which the UK exits the EU and the costs of so doing - is being ignored (see Figure 1 of the Executive Summary)..

The material here is of three kinds. First (in Section 2) we provide a discussion of the economics of trade and of the ways in which trade affects the economy. There is still considerable confusion in UK debate, for example between the Single Market and the Customs Union, which are often viewed as much the same thing (they are very different). Also the mental models of many journalists and politicians are drawn from the last period when trade arrangements were at the centre of UK political debate, i.e. at the time of the abolition of the corn laws in the first half of the19th century. International trade today is very different than two centuries ago, with manufacturing based on international supply chains across many countries and services accounting for a major share of all trade (this is especially true for the UK). This section also contains a review of current research on the economic impact of re-organising UK trade arrangements post-Brexit.

Second (in Section 3) we summarise the institutional arrangements that support international trade and the lowering of barriers to trade. These involve both tariff barriers and most importantly non-tariff barriers. The main point we make here is that UK trade, as they have developed over the past half century as members of the EU, rely heavily on participation in the European Customs Union and in particular, with regard to non-tariff barriers, the EU Single Market. While both can be replaced with new arrangements that do not require us to be memb3ers of the European Union, this is a complex task that will take several years. We also in this section discuss 
some of the challenges involved in renegotiation of trade arrangements. While new arrangements can be reached in which the barriers to trade between the EU and the UK are about as low as they are today, and in which we have greater freedom than we currently have to establish our own trading relationships with the rest of the world, It is clear that it will take several years, we think with good will and hard work around five years, to agree this new framework.

Finally (in Section 4), we present some descriptive statistics and visualisation of trade data, with the aim of providing key factual information to a broad audience. This material, which can be omitted on a first reading, reinforces the analysis of Sections 2 and 3, confirming that the UK currently relies to a large degree on trade with the EU and with other European countries. While there is scope for trade agreements that support expansion of trade with countries outside of the EU (we argue on the basis of our review of these statistics that a free trade agreement with Switzerland should be the first priority for a new arrangement of this kind) the benefits of these new arrangements will only accrue slowly and gradually and will be far too small to compensate for an abrupt dislocation of trade with the European Union.

Our executive summary does NOT seek to repeat the detailed information contained in this briefing (which is already a summary of a wide range of information). Instead it presents what we take to be the central message of the large body of available research on trade arrangements after Brexit (some sponsored by the ESRC who have also supported our work). While new arrangements can certainly be found outside of the EU that facilitate UK trade across the world without imposing substantial costs on UK households and businesses, this is a complex task (we make the analogy to planning and then building a new house) which will take 5 to 7 years. Attempting a rapid Brexit in one to two years will impose a fall in UK per capita consumption and GDP of the order of 5 to $8 \%$.

It is a political decision whether, in the light of the referendum result, the UK will pursue a rapid but costly Brexit or a slow and managed Brexit with full and careful negotiation of new trade agreements to minimise tariff and non-tariff barriers to trade and hence avoid substantial costs on the UK economy. It is the responsibility though of the research community to make those taking this decision aware that rapid Brexit with an immediate departure from the Single Market and European Customs Union in March 2019 will be extremely costly when compared to the alternative of a managed transition process lasting 5-7 years.

We also note that failure to recognise the complex challenges and time involved in creating new trading arrangements threatens a tragic outcome. The UK may well end up being forced, by political shortsightedness and refusal to compromise, into a costly rapid Brexit even though this is an outcome that no-one actually wants. 


\section{The economics of international trade and international}

\section{trade arrangements: a sketch}

\section{a. The Economic Rationale for Free Trade}

As we teach our undergraduate students, the economic rationale for trade is essentially the rationale for specialisation in general. I am an apple grower, but am short of wheat. My neighbour grows wheat, and is short of apples. The reason I sell apples is because it enables me to purchase wheat.

The same rationale applies to trade. The gain from trade is that the goods which we import are worth more to us than the goods which we export (but to someone else, the goods we sell them are worth more to them than the goods they sell us). Hence exchange is valuable.

So the basic purpose of trade is to import. Exports are the price to us of those imports. This also means that the benefits of trade depend on the terms of trade, the more favourable are the terms of trade (i.e. the more imports per unit exported) then the larger the economic gain from trade. The benefit of an improvement in one country's terms of trade (whether from an appreciation in the exchange rate or an increase in the prices of its exported traded goods and services) is usually, however, matched by a deterioration in other countries terms of trade.

For understanding the impact of trade arrangements, economists start by considering a 'small' country, which cannot manipulate its terms of trade (because it faces too much competition to be able to drive up its export price by restricting supply).

This is contrasted with a 'large' country, or conglomerate of countries (e.g. a Customs Union), which can drive up their export prices at the expense of their neighbours.

However, any country which produces differentiated goods can manipulate its terms of trade. This means that in economic terms almost no country is small.

Econometric studies suggest that most countries face an elasticity of demand for their exports of around $5 .{ }^{4}$ This means that a $1 \%$ rise in export prices (or in tariff and non-tariff barriers to trade) leads to a $5 \%$ fall in export volumes (over time).

\footnotetext{
${ }^{4}$ Head, K., \& Mayer, T. (2014). Gravity Equations: Workhorse,Toolkit, and Cookbook. In G. Gopinath, E. Helpman, \& K. Rogoff (Eds.), Handbook of International Economics Vol 4. (pp. 131-195). Elsevier. https://doi.org/10.1016/B978-0-444-54314-1.00003-3 present a meta-analysis, which pools the results of a large number of studies of international trade.
} 
A country can drive up its export price by a number of means. However, the simplest way is to restrict its own demand for imports from its neighbours, by a tariff. Say Britain puts a tariff on its imports. This leads to a trade surplus, which drives up the value of sterling. Consequently, the price (to our neighbours) of exports increases. We are purchasing more imports per unit export, and feel better off.

Of course, if everybody does this, then trade is more costly and the gains from trade are reduced.

The rationale for bilateral (or multilateral) trade liberalisation can be seen in terms of the Prisoner's Dilemma. Table 1 below shows Britain and France's welfare in response to different trade policies (for each cell, the first number represents France's welfare, the second number represents Britain's welfare).

Table 1: trade agreements as a 'prisoner's dilemma'

\begin{tabular}{|l|l|l|l|}
\hline & & France & \\
\hline Britain & $\begin{array}{l}\text { Impose trade } \\
\text { barrier }\end{array}$ & $\begin{array}{l}\text { Impose no trade } \\
\text { barrier }\end{array}$ \\
\hline & $\begin{array}{l}\text { Impose trade } \\
\text { barrier }\end{array}$ & 100,100 & 50,160 \\
\hline & $\begin{array}{l}\text { Impose no trade } \\
\text { barrier }\end{array}$ & 160,50 & 125,125 \\
\hline & & & \\
\hline
\end{tabular}

Collectively, both countries are better off with no trade barriers than in the cases where with either one imposes a trade barrier, or where both impose a trade barrier. However, consider how Britain responds if it takes French policy as given.

If France imposes a trade barrier, Britain is better off (100 against 50) imposing a trade barrier itself. And if France imposes no trade barrier, Britain is better off (160 against 125) imposing a trade barrier.

The same logic applies to France. So in the absence of cooperation, Britain and France will both impose trade barriers. But both can make themselves better off by making an agreement not to impose trade barriers on each other.

\section{b. Bargaining power}

Whether or not the two countries, in a situation such as Table 1, are able to agree to a co-operative outcome and the extent to which they can capture the gains from cooperation, depends on their bargaining power. Table 1 assumes that the situation is symmetric. But the threat i.e. not to co-operate is less effective the greater the loss when comparing the co-operative and non-cooperative outcome. If this loss is large, then a country is mostly likely to agree to co-operate and to accept a relatively small share of the overall gains of co-operation. 
So how much bargaining power the UK will have in the negotiation of low trade barriers with the remaining EU members? In terms of the standard rationale for free trade (i.e. that the purpose of exporting is to purchase imports and hence increase consumption possibilities) the issue is then how large is the overall increase in trade, exports and imports, from a reduction in barriers to trade. If a country relies to a relatively large extent on a particular trading partner for imports and exports, and (as is generally accepted for most traded goods and services) the price elasticities of demand are relatively low, then it faces relatively great costs from imposing reducing barriers to trade and is in a weak bargaining position.

The key issue is thus dependence. If country A depends more for its exports and/or imports on country $B$ than the other way around, then it has fewer alternatives, and is in a less strong bargaining position. It is the importance of the partner in total exports and imports, not the trade balance, which matters.

On this basic criterion, the UK is in a rather weak position relative to the rump EU (Table 2). This table suggest that UK citizens would suffer approximately four times as much as EU citizens from a failure to reach a co-operative solution for our trade arrangements once the UK leaves the EU. Hence the UK is in a weak bargaining position. [This is the direct opposite of the conclusion reached by many commentators, who have argued that because the EU exports a lot more to the UK than the UK exports to the EU that the UK has a stronger bargaining position than the UK.]

Table 2: UK - EU27 trade as a share of their respective total global trade.

\begin{tabular}{|l|l|l|l|l|}
\hline $\mathbf{2 0 1 1}$ \$m & UK & & & UK \\
\hline Imports from EU27 & 418743.2 & & Exports to EU27 & 348441.5 \\
\hline All imports & 858485.1 & & All Exports & 676202.5 \\
\hline EU27 \% & $48.78 \%$ & & EU27\% & $51.53 \%$ \\
\hline & & & & \\
\hline & EU27 & & & EU27 \\
\hline Imports from UK & 348441.5 & & Exports to UK & 418743.2 \\
\hline $\begin{array}{l}\text { Imports from outside } \\
\text { EU27 }\end{array}$ & 2964446 & & $\begin{array}{l}\text { Exports to outside } \\
\text { EU27 }\end{array}$ & 2800381 \\
\hline UK \% & $11.75 \%$ & & UK \% & $14.95 \%$ \\
\hline
\end{tabular}

However, we are ignoring the effects on particular interest groups, those individuals whose livelihoods are closely tied to the performance of export industries (for example German motor manufacturers and their employees). It is true that these interest groups are likely to be organised and vocal, so to that extent the EU may be reluctant to exert its bargaining power as strongly as is suggested by Table 2. As discussed in the next sub-section, such distributional impacts are an important consideration.

There are also political pressures for the EU to 'punish' the UK in order to deter other member states from leaving the EU. While exporters may suffer, they have many 
other export markets and overall there seems relatively little, in terms of the impact on EU citizens as a whole, to prevent EU negotiators achieving an outcome in which the UK loses relative to our current membership of the EU. Ultimately this is an issue of diplomacy - both sides can lose from a bad deal - so we need frank, friendly and constructive dialogue, over a period of years, to achieve a good outcome.

\section{c. Distributional impacts, structural rigidities and special interest lobbying}

Given that the purpose of trade is to consume, why then does almost all media and political discussion focus instead on the promotion of exports as a goal in its own right? One reason is that the standard economic analysis of the economics of free trade as we have recounted it, in which the purpose of trade is to acquire imports to increase consumption possibilities, omits the distributional impacts of trade liberalisation and its impacts on particular groups.

Agreement between two countries to lower trade barriers can be expected to increase consumption possibilities for both. This though does not guarantee that all citizens of both countries are able to consume more than would be possible for them without a trade agreement. Within any individual country, many people's incomes are tied up with exporting a particular good, or in competition against or co-operation with imports of a particular good, and also maybe with trade to a particular destination.

This is an important issue, even though trade economists usually view it as secondary. There many possible ways of compensating people for losses from trade agreements, for example via specific retooling or re-training programmes, as well as regional subsidies or the tax and benefits system. Still it must be recognised that this compensation will not always happen. The challenges of redistribution are greater if there are structural problems which result in underemployed resources (labour of human and physical capital) in some regions or amongst some population groups and hence expose some citizens to relatively large potential income losses. Even with the usual tools of redistribution such as progressive taxation and social security benefits, the reduction of trade barriers will result in losers as well as gainers.

This in turn means that any discussion about changes to trade arrangements will be accompanied by intense lobbying from domestic special interest groups, seeking to obtain exceptions or special concessions that will give them particular advantage; and potentially substantial political opposition, especially when losers are able to form effective political coalitions.

\section{d. Dynamic gains from trade}

Reducing trade costs can yield further substantial benefits by raising productivity: i.e. the so called dynamic gains from trade.

One reason for this is that traded goods are an important input into production. These inputs are not just intermediate inputs, but also capital goods. For example, in 
the UK in 2014, almost half of all output was accounted for by intermediates expenditure and nearly one quarter by fixed capital (Figure 2).

Figure 2: UK Industry's Costs.

\section{UK Industry's Costs 2014. Total $\mathbf{f 3 . 1 4}$ tr. UK Input-output tables}

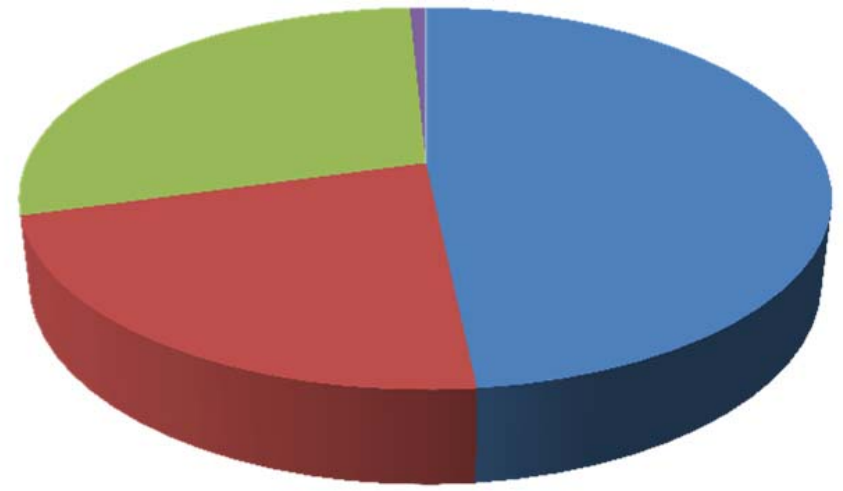

Intermediates

- Capital

Wages

- Taxes

In total some $70 \%$ of total costs are attributed to intermediates and capital. Cheaper imported inputs, whether from reductions in trade barriers or improvement in the 'terms of trade', mean more of these will be used per head and productivity is increased.

In addition, there are scale-related gains. This reflects two important factors:

1. Larger markets give access to a greater variety of more specialised inputs, which raises productivity.

2. Larger markets allow firms to carry out more R\&D expenditure, and raise innovation.

These gains are largest in the situation where goods are differentiated and there are economies of scale in production, so that there are a relatively small number of competing producers (imperfect competition).

Most industries, both in goods and in services, are imperfectly competitive. For these industries reducing barriers to trade is especially important, for both static and dynamic reasons.

- With economies of scale in production, lowering barriers to trade allows greater specialisation of production, lowering costs and increasing the choice of products available for consumption (a static gain)

- As barriers to trade are lowered, the rate of innovation increases, leading to faster increases in productivity, more growth and in turn creating even greater incentives for innovation==> A VIRTUOUS CIRCLE (dynamic gain). 
- Protection, on the other hand, has the opposite effect, reducing specialisation of production (a static loss) and leading a slowdown in productivity, less growth, and reducing incentives for innovation ==> A VICIOUS CIRCLE (a dynamic loss).

\section{e. Supply Chains}

A further consideration, when assessing the economic consequences of altering trade arrangements, is that most modern industries, especially complex manufactured products such as vehicles or electrical goods, employ extended supply chains with many stages of fabrication carried out by different firms. Many of these are international, linking firms (or branches of firms) across countries. The emergence of modern information and communication technologies (the internet) has played an important role in supporting extended supply chains.

One indication of the importance of supply chains is the high proportion of intermediate inputs in industry costs shown in Figure 2 (this is an average, for many individual sectors the share of intermediate inputs is even higher).

The successive stages of these supply chains involve specialist relationships between producers. This is particularly true when - as is the case in many industries today - goods and services are highly differentiated. Firms then have to make relationship-specific investments (for example designing products and distribution systems) to suit their main customers. This in turn creates a number of challenges that do not arise for the case of trade in standardised products. Direct ownership may be preferred over a market relationship in order to internalise the high transaction costs associated with complex products. Where direct ownership is not possible then goods are delivered subject to a contract. This is dependent upon legal institutions to ensure that the contract is enforced.

There has thus been is a shift in the nature of trade. Nowadays international exchange no longer consists largely of raw materials and finished goods and services but also to a large extent of goods at various stages of fabrication and services that input into production processes. Trade is supported by a complex supporting web of business relationships both within and between firms.

This has a number of economic consequences:

- Current patterns of trade, both domestic and international, are the cumulative outcome of past investments - not just in fixed capital such as plant and machinery, but more importantly in intangible capital such as patents, business processes and employee training.

- Much international trade, especially in sophisticated manufactured products, is based on intra-regional supply chains, strengthened by the relatively close legal and cultural affinities of neighbouring nations as well as comparatively low transportation costs. Thus, while the UK, sends a substantial volume of manufactured exports to the United States, we also use as inputs to these 
exports a substantial volume of manufactured intermediate and capital goods imports from the rest of Europe.

- For other products, where stages of production rely on unskilled or semiskilled labour, supply chains may extend inter-regionally from lower wage developing economies to higher wage developed economies. Arguably this has substantially altered the distributional impact of free trade arrangements, with reduced tariff barriers resulting in greater international competition in the supply of unskilled and semiskilled labour and falling real wages and employment in the developed world.

- As a consequence of the greater complexity and internationalisation of production, trade agreements are themselves becoming increasingly complicated and difficult to execute. The WTO's Doha round, its most recent effort at global reduction in barriers to trade, broke down in 2008 with particular problems in reaching agreement on agricultural trade and in bridging the opposing interests of developing and developed nations. Subsequent efforts at agreeing trade arrangements have been regional, including the efforts at reducing non-tariff barriers within the EU single market.

- Arguably, for the many industrial sectors characterised by imperfect competition, taking full advantage of the potential static and dynamic gains from the international organisation of production requires low barriers to trade, especially at regional level.

This also means that the trade patterns we see today are in large part the outcome of past investment in trading relations. Manufacturers develop international networks of suppliers and design their production processes around co-operation with their principal partners. Governments also invest, in trade agreements to reduce trade $b$ arriers and in the systems and processes to manage remaining tariffs and checks on compliance with regulation and standards. Taking all this into consideration, means first that changes in trade take a considerable amount of time to fully respond to shocks (such as new trade arrangements). This means that the benefits of the EU single market will not disappear overnight, but continue for many years to come (although the introduction of lengthy process of border inspection to replace mutual recognition would have an immediate impact on costs of production). It also means that that benefits of re-orientating trade patterns, e.g. to greater trade with North America, will take a long time to come through, with a very slow build up of investment in new supply chains. The worst outcome would be a disorderly or even hostile departure from the EU, disrupting existing supply chains, because there would be no compensating benefits from trade agreements outside of the EU for some years to come.

The past investment in existing trade relationships is a principal reason why the trade impact of a rapid Brexit will be costly. The trade impact of a slow and managed Brexit carried out over several years will be very different, allowing existing 
investments to be maintained and for new investments to be made and resulting in comparatively low costs to the UK and very possibly substantial net economic gain.

\section{f. Examples of individual industries: motor cars and financial services} Our conference of Dec $9^{\text {th }}, 2016$ offered detailed discussion of two individual industries, motor cars and financial services. These two industries also illustrate issues that can affect other sectors: the international nature of supply chains and the importance of local 'agglomeration' effects. .

Motor production has been a UK success story over the past decade, with the volume of exports more than doubled $2005-2015$. $80 \%$ of this output (1.2 million vehicles) is exported, amounting to $12 \%$ of the value of all UK exports. $57 \%$ of car exports go to EU. Even more cars (2.2 million) were imported or taken from stock, but the UK has more of the premium higher unit value end of market. $12 \%$ of car exports go to emerging markets.

UK car manufacturers are the highest productivity in Europe and employ about 800,000 people including in supply and distribution. They have achieved strong productivity growth (unlike rest of UK economy), with several plants operating 24/7 using three shifts a day.

The average UK content of a UK made car has risen slowly from $30 \%$ to $40 \%$ over the past six or seven years. The UK car industry is a primary example of the international nature of modern supply chains. Car companies work with primary first line suppliers who serve as 'module integrators' i.e. sourcing and bringing together individual compnents. Parts of a UK made car can cross borders five or six times in the course of production. The UK is also a major exporter of car parts e.g exports of engines 2.5 million per year (a large proportion then exported for assembly in the $\mathrm{EU})$. All this is based on substantial recent and continuing investments in supply chains.

Davies et. al. (2014) report information on source of car parts for UK industry $-27 \%$ Germany, 10\% France, 31\% other EU, 9\% Japan, 3\% Turkey, 4\% China, 20\% Rest of the World. ${ }^{5}$ The car industry is global but with regional concentration. If the UK is faced with tariffs on exports to and imports from the EU for cars and car parts then clearly this will have an impact on the profitability of existing production arrangements, raising the question of whether major manufacturers might transfer production to factories within the EU. According to David Bailey, presenting at our conference, the investments at most risk of closure between 2018 and 2024 are likely to be those of Honda and Toyota $m$ because they already have relatively low margins and profitability and are operating below full capacity. Mini, Nissan and

\footnotetext{
${ }^{5}$ Davies, P., Holweg, M., Hugget, N., Schramm, S., \& Tran, Y. (2014). Growing the automotive supply chain: Assessing the upstream sourcing potential. Automotive Council UK.
} 
Vauxhall UK plants much more successful though the possibility of moving production to EU will still be considered. The niche luxury brands Jaguar-Land Rover, Bentley and Aston Martin are very unlikely to move. A range of factors will go into decision, not just costs, for example the time and trouble of applying 'rules of origin' if the UK is out of the European customs union and establishing conformity with national or EU regulations will be important considerations.

Industry needs single market, customs union (or at least special rules of origin) and rules on hiring skilled workers from the EU (currently around 5000 critical skilled vacancies in UK car industry, one in ten workers from another EU country). The EEA is more than just a free-trade area, it is about access to the single market, within it there is a regulatory agreement, for example the mutual recognition of conformity assessment so that a car that is made in country that is part of that deal is not subject to technical inspections if it is sold in another country. An outcome without a tailored low tariff and mutual recognition and conformity with standards will be problematic for car industry. In the past the UK has been very successful at shaping EU regulations to ensure did not disadvantage UK car manufacturers, but this will be more difficult going forward.

Financial services are another UK success story. Not only are financial services a major employer they also, through the wholesale services provided in London, make a major contribution to UK trade (Table 3).

Table 3: The Trade Contribution of the City

\begin{tabular}{|l|r|r|r|}
\hline \multicolumn{1}{|c|}{ 2015, fbn } & Credits & Debits & Balance \\
\hline Fund management & 5.4 & 0.9 & 4.4 \\
\hline Securities dealers - trading income (cfts) & 6.2 & 0.1 & 6.1 \\
\hline Monetary financial institutions - cfts & 18.5 & 2.9 & 15.6 \\
\hline Monetary financial institutions - interest spreads & 7.1 & 2.2 & 4.9 \\
\hline Baltic exchange for shipping (provisional data) & 0.3 & 0.0 & 0.3 \\
\hline Other financial services & 13.3 & 2.4 & 10.9 \\
\hline Life and general insurance & 10.2 & 0.0 & 10.2 \\
\hline Reinsurance and insurance services & 2.7 & 0.1 & 2.5 \\
\hline Law, accounting and management consulting & 17.1 & 7.0 & 10.1 \\
\hline Total & 80.7 & 15.8 & 64.9 \\
\hline
\end{tabular}

Notes: Authors calculations from Pink Book 2016, Sections 3.4, 3.5 and 3.8 cfts $=$ commissions, fees and trading spreads

Note from Table 3 that one third of the City of London trade balance come from the commissions, fees and spreads (cfts) associated with trading in foreign exchange, security and derivative markets. Much of 'other financial services' - for example 
clearing (trade guarantees) and securities settlement - are also associated with trading. The other main activities are bank deposit taking; bank credit, insurance and reinsurance; law and management consulting and (a smaller contribution, less than one tenth of the trade balance) fund management.

The impact of Brexit on trade in financial services was addressed in short presentations at our conference by Michael Mainelli and Alistair Milne. It is clear from close examination that 'passporting' is a much less important issue for the future of financial services than much press discussion has suggested.

Some have argued that the loss of EU 'passporting rights' on the City of London would lead to a substantial loss of export revenue. One widely cited example is the Oct, 2016 report of City UK/ Oliver Wyman, which found that 40-50\% of EU-related activity (approximately £18-20bn in revenue) and up to an estimated 35,000 jobs could be at risk, if the UK was to exit the EU without any arrangements for recognising the right of UK institutions to continue selling financial services to EU customers. $^{6}$

It is difficult to square this City UKI. Oliver Wyman analysis with the official balance of payments statistics shown in Table 3. UK trading and most banking and insurance services involves clients coming to London e.g. to execute trades, to deposit or borrow money or to take out insurance. Since OECD rules preventing the introduction of capital controls will apply to both the UK and to all EU countries after Brexit, clients will still be able to come to London to access these financial services, even those in Euro, and certainly those in dollars, Yen, sterling or minor currencies such as Australian, Canadian and New Zealand dollars, regardless of any trade agreements with the EU.

If the UK fails to maintain 'passporting rights' for UK based firms this would have a substantial impact on the ability to provide some financial services across the EU. This is an issue for two main groups of City firms: (i) that part of the asset management industry which serves retail or smaller institutional clients in other EU countries; and (ii) banks of non-EU countries that have established subsidiaries in London in order to provide pan-European banking and foreign exchange services to their domestic corporate clients.

While an exact figure for export earnings for these firms cannot be computed from the statistical sources used to compile Table 3, a very generous estimate would be around two fifths of asset management ( $£ 2 \mathrm{bn}$ ) and around one tenth of the earnings of monetary financial institutions ( $£ 2.5 \mathrm{bn})$. It is difficult to understand, given this total figure of total revenues threatened by loss of passporting of $£ 4.5 \mathrm{bn}$, how there could

\footnotetext{
${ }^{6}$ City UK/ Oliver Wyman. (2016). The impact of the UK's exit from the EU on the UK-based financial services sector.- executive summary. Retrieved from http://www.oliverwyman.com/content/dam/oliverwyman/global/en/2016/oct/Brexit POV.PDF
} 
possibly be an overall revenue loss of $£ 18 \mathrm{bn}$. The Oliver Wyman figures seem to be an order of magnitude - I.e. ten times - too large (possibly reflecting the fact that their client and co-author was the City lobbying group City UK).

More realistic analysis of the impact of Brexit on the City of London have been provided by Singham (2016) and Reynolds (2016). ${ }^{7}$ As they point out there are many myths about financial services trade in the EU. Most importantly despite great efforts by the European Commission to promote a single market in financial services there is at present very little cross-border trade in retail financial services. It is of course possible that in future decades such cross-border retail financial services activity will grow in importance and the UK being outside of the EU will not participate in this growth.

Another somewhat exaggerated issue is the potential move of Euroclearing from London to the continent. While EU authorities, on grounds of ensuring financial stability, may insist on all Euro denominated 'clearing' (mutual guarantees on the completion of security and derivatives trades) taking place in Euro area financial centres, this will of itself make little difference to the cost-competitiveness of London as a financial centre. As Mainelli argues in our conference, the rise of the City of London as a financial centre since 1945 is based on a wide number of competitive advantages, including language, infrastructure, supply chains and human capital. This agglomeration of activity has been self-reinforcing, further investments in London to take advantage of its competitive advantage over other international financial centres reinforcing those competitive advantages.

A more substantial issue for the City of London, and indeed for the motor manufacturing industry and other sectors, are potential restrictions on the ability to bring in skilled labour from around the EU to work in the UK. The City of London has a very international workforce. Some EU citizens working in financial services in London are feeling that their future in the UK is uncertain and as a result may decide to leave the UK.

An argument suggesting that Brexit will favour UK financial services, made by both Singham and Reynolds, is release from the constraints on UK financial services from pan-European financial regulation. There are many examples where regulation written to work across 28 jurisdictions limits activities that would be possible under a more permissive national regime. While the subject merits much closer examination than we are able to give to it, it is certainly possible that in order to encourage innovation - e.g. in newly emerging technology based competition for banks and

\footnotetext{
${ }^{7}$ Singham, S. A. (2016). Brexit and Financial Services. Retrieved from https://lif.blob.core.windows.net/lif/docs/default-source/default-library/post-brexit-briefing-financialservices-september-2016-pdf.pdf?sfvrsn=4 ; Reynolds, B. (2016). A Blueprint for Brexit: The Future of Global Financial Services and Markets in the UK. Retrieved from http://www.politeia.co.uk/wpcontent/uploads/2016/11/Barnabas-Reynolds-A-Blueprint-for-Brexit-2.pdf
} 
insurance companies - the UK may benefit from being outside of the existing framework of EU financial regulation.

Overall it seems that the threat posed to the UK's financial services by Brexit has been greatly exaggerated. Also and pertinently, given the relatively unimportance of passporting for UK interests, it is very possible that once after Brexit trade negotiations begin in earnest the UK government will want to be in a position to concede on claims to recognise passporting of UK financial services firms in order to extract some other concession from the EU to benefit a different UK industry.

\section{g. Estimates of Static and Dynamic losses/gains from Brexit}

Given this wide range of contributing factors, is should come as no surprise that there is a wide range of estimates of the costs for the UK of replacing existing EU trading arrangements. Different modellers use a variety of modelling techniques and assumptions: some have utilised a microeconomic-based computable general equilibrium (CGE) or related approach, while others have taken microeconomic estimates of costs and inserted them into macroeconomic models. Some allow only for static impacts others allow for dynamic as well. Table 4, taken from a 2016 Institute of Fiscal Studies (2016) paper covers a number of estimates: ${ }^{8}$

The first impression from this table is the wide range of estimates of the long-run economic impact of Brexit, ranging from the 7.8 and 7.9 percent decline in GDP from the NIESR and the Centre for Economic Performance to the +4 percent increase in GDP from Economists for Brexit. Most estimates are negative, may are large and negative, with only two positive, a modest positive impact according to Open Europe and a larger positive impact according to the Economists for Brexit.

\footnotetext{
${ }^{8}$ Emmerson, C., Johnson, P., Mitchell, I., \& Phillips, D. (2016). Brexit and the UK's public finances. Institute for Fiscal Studies Report, 116. Page 18.
} 
Table 4: Estimates of the long-run economic impact of Brexit

\begin{tabular}{|c|c|c|c|c|}
\hline Organisation & Scenario & $\begin{array}{l}\text { Estimate } \\
\text { (\% GDP) }\end{array}$ & Range & Impacts modelled \\
\hline \multirow[t]{3}{*}{ CEP (LSE) } & $\begin{array}{l}\text { Dynamic } \\
\text { EEA/FTA }\end{array}$ & -7.9 & $(-6.3$ to -9.5$)$ & Budget, trade, productivity \\
\hline & StaticEEA & -1.3 & N/A & Trade only \\
\hline & Static WTO & -2.6 & $\mathrm{~N} / \mathrm{A}$ & Trade only \\
\hline \multirow[t]{3}{*}{ HM Treasury } & EEA & -3.8 & $(-3.4$ to -4.3$)$ & \multirow{3}{*}{$\begin{array}{l}\text { Budget, trade, FDI, } \\
\text { productivity }\end{array}$} \\
\hline & FTA & -6.2 & $(-4.6$ to -7.8$)$ & \\
\hline & WTO & -7.5 & $(-5.4$ to -9.5$)$ & \\
\hline OECD & WTO/ FTA & -5.1 & $(-2.7$ to -7.7$)$ & $\begin{array}{l}\text { Budget, trade, FDI, } \\
\text { productivity, migration, } \\
\text { regulation }\end{array}$ \\
\hline \multirow[t]{4}{*}{ NIESR } & EEA & -1.8 & $(-1.5$ to -2.1$)$ & \multirow[t]{3}{*}{ Budget, trade, FDI, } \\
\hline & FTA & -2.1 & $(-1.9$ to -2.3$)$ & \\
\hline & WTO & -3.2 & $(-2.7$ to -3.7$)$ & \\
\hline & WTO+ & -7.8 & $\mathrm{~N} / \mathrm{A}$ & Adds productivity \\
\hline \multirow[t]{2}{*}{$\mathrm{PwC} / \mathrm{CBI}$} & FTA & -1.2 & \multirow[t]{2}{*}{$\mathrm{N} / \mathrm{A}$} & \multirow[t]{2}{*}{ Budget, trade, FDI, regulation } \\
\hline & WTO & -3.5 & & \\
\hline $\begin{array}{l}\text { Oxford } \\
\text { Economics }\end{array}$ & FTA $^{a}$ & -2.0 & $(-0.1$ to -3.9$)$ & $\begin{array}{c}\text { Budget, trade, } \mathrm{FDI}, \text { migration, } \\
\text { regulation }\end{array}$ \\
\hline Open Europe & FTA & -0.8 to +0.6 & $(-2.2$ to 1.6$)$ & $\begin{array}{l}\text { Budget, trade, migration, } \\
\text { regulation }\end{array}$ \\
\hline $\begin{array}{l}\text { Economists } \\
\text { for Brexit }\end{array}$ & WTO & +4.0 & N/A & Budget, trade \\
\hline
\end{tabular}

Source: Institute for Fiscal Studies, citation above.

In fact there is much less discrepancy of view about the economic mechanisms than this first impression given by this table would suggest. There are two main reasons why these projections differ:

- The first is whether they look only at static impacts arising from higher costs of trade or if they also allow for the further dynamic impacts on productivity growth and investment. As we have already argued dynamics effects are important determinants of trade volumes and the economic gains from trade. The experience of the UK car industry in the past decade, reviewed above, provides an excellent illustration, the initial advantages of car manufacturing in the UK have been reinforced by investment and efficiency gains as scale of operations has increased, leading to further productivity gains. While these dynamics are notoriously difficult to model, they can be expected to substantially increase either the gains or losses of Brexit, possibly by a factor of two or more. ${ }^{9}$

\footnotetext{
${ }^{9}$ Interestingly, the economist best known for theoretical modelling of dynamic gains from trade, Paul Krugman, deliberately chose a model excluding such gains when he produced back-of-envelope calculations (of a GDP loss of 2\% from Brexit) in June 2016.

http://krugman.blogs.nytimes.com/2016/06/12/notes-on-brexit/? $\quad r=0$
} 
- The second is the assumptions made about the impact of Brexit on the costs of international trade. ${ }^{10}$ Take for example the positive $+4 \%$ projection of the economic impact of Brexit from Economists for Brexit. Their modelling of the costs of trade allows only for tariff, not non-tariff, barriers to trade with the further assumption that the UK, once outside of the $\mathrm{EU}$, is able to negotiate zero-tariff deals with all our trading partners around the world and hence substantially reduce overall costs of trade. Compare this with the negative forecasts of NIESR, the Centre for Economic Performance and HM Treasury take the opposite tack. These focus on non-tariff barriers assuming that the non-tariff barriers to trade with the EU increase substantially unless we remain in the EEA. So this is a comparison on apples with oranges, the different projections reflecting not so much the modelling but the different assumptions made about future costs of international trade (Brexit has little impact costs of trading with the EU and reduces trading costs overall v. Brexit has a major impact on the costs of trading with the EU and increases trading costs overall.)

Whether the actual outcome is more extreme negative or the more positive economic projections from this table depends very much on how Brexit is implemented. The Economists for Brexit scenario, assuming non-tariff barriers are not increased by Brexit, is a plausible one provided we negotiate a deep and comprehensive trade agreement both between the UK and the EU, and between the UK and other countries such as Switzerland and the United States after Brexit, covering all the principal industries in which we engage in international trade, including our service industries and ensuring that they are not affected by non-tariff barriers.

As we will discuss in Section 3, when we look at the institutional arrangements for international trade, such an outcome is achievable but it will take time and effort, we believe with good will an EU-UK trade deal will take around five years. The Economists for Brexit projection then becomes credible.

The more negative projections assume instead a substantial increase in non-tariff barriers to trade with the EU. Two of these (those of the LSE Centre for Economic Performance and of NIESR) were presented at our conference of Dec, 2016. Focusing on the NIESR work, this (to simplify somewhat) assumes an increase in costs of trade with the EU, as a result of higher non-tariff barriers, equivalent to an average tariff of around $10 \%$ and as a result ('ceteris paribus' i.e. other things held constant) a fall in the value of UK trade with the EU of $50 \%$ and of overall UK trade

$\mathrm{E} \mathrm{on}^{10}$ The IFS attempt to summarise these assumptions under three main headings: EEA (meaning an arrangement similar to Norway in which the UK continuesto participate in the Single Market and possibly also customs union); FTA (meaning a tailored deep and comprehensive trade agreement between the UK and the EU which maintains some but not all the benefits of participation in the Single Market); and WTO (meaning that there is no arrangement with the EU other than that immediately obtainable from applying WTO rules). This three-way split however does not adequately capture the different forecasting assumptions. 
with the rest of the world of around $25 \%$. Their modelling is undertaken very carefully, allowing for the patterns of trade in intermediate as well as final goods and assuming relatively limited impact of free trade agreements on trade in services (Economists for Brexit appear to assume instead that future trade deals by the UK can substantially lower the costs of trade in services, but the little evidence we have from past free trade agreements seems to suggest that these do not have much impact on services exports).

NIESR then employ their multicountry NIGEM model of the world economy to investigate further offsetting second round impacts, most notably a decline in sterling exchange rate which serves to boos t our exports and trade. The rather pessimistic NIESR projections are a credible outcome, assuming we pursue Brexit rapidly and fail to spend the years ahead negotiating a deep and comprehensive deal between the UK and the EU in order to prevent a substantial rise in non-tariff barriers to UKEU trade.

Thus we see that the apparent divergence of views amongst different economic forecasters is, in reality, a difference in assumptions about the implementation of Brexit. Economists for Brexit assume that this is managed well and that we do not experience any substantial increase in costs of our external trade. Most other forecasters assume that implementation of Brexit is unable to avoid a substantial increase in costs of our external trade, primarily because we are unable to find a substitute arrangement that achieve the same lowering of non-tariff barriers for EUUK trade that is currently achieved through our participation in the EU Single Market.

The key question is then what is required to manage Brexit well and avoid substantial increases in the costs of external trade. Our view, as we have made clear and discuss further in Section 3, is that preventing a rise in non-tariff barriers to UKEU trade will require several years of negotiations after the UK has left the EU. We assume that Economists for Brexit are a good deal more optimistic than we are on the time framew for such negotiation, believing that an effective deal between the UK and the EU to prevent a substantial increase in non-tariff barriers to trade(product standards, regulations etc.) can be sorted out comparatively quickly. But even if this can be done in say one or two years, detailed negotiations cannot begin until close to or even after the UK has left the EU. Therefore, if the positive outcome predicted by Economists for Brexit is to be achieved, there is no alternative to negotiating an interim period of continued membership of the Single Market for least a couple of years after March 2019 (the end of the Article 50 process).

During this time the UK will one must assume be obliged to continue with both contributions to the EU budget and to accepting freedom of movement of labour. Our own view is that a five year period of interim participation in the Single Market will be needed, but even this is uncertain, so it would be unwise to impost any fixed time limit on this interim participation in the Single Market cannot. Of course if negotiation of a replacement deep and comprehensive free trade agreement can be completed 
in much less than five years, then the interim arrangement can be ended relatively soon.

By the same token, the predictions of NIESR, the LSE Centre for Economic Peformance and others seem unduly pessimistic. Provided an open-ended postBrexit interim participation in the Single Market is agreed, then there is no reason for non-tariff barriers to trade to rise to the extent that their projections assume. A tailored deep and comprehensive free trade agreement between the UK and the EU, covering all important non-tariff barriers to UK-EU trade, will mean that the costs of UK-EU trade do not arise anything like as much as these forecasts assume.

Indeed it is very possible that our leaving the European Single Market and European Customs Union, could over time yield substantial economic benefits to the UK. To give one example, as we have already discussed, departure from the EU could be beneficial to UK financial services, allowing the the UK to tailor the regulation of this strong export sector to support international trade in financial services. A strong case can be made for the benefits of similar freedoms for trade in other agriculatural, industrial and service sectors. ${ }^{11}$

\footnotetext{
${ }^{11}$ See Singham, S. A. (2017). A Blueprint for UK Trade Policy. London. Retrieved from https://lif.blob.core.windows.net/lif/docs/default-source/default-library/170427-final-tradeblueprintweb.pdf?sfvrsn=0 for an optimistic and largely persuasive account of the benefits of such freedpm for the UK to conduct its own trade arrangemetns; Singham though does not provide any detailed assessmentof the time scale for reaping these benefits which could be relatively slow.
} 


\section{The Institutional Arrangements}

This section reviews the institutional arrangements that govern international trade, and the extent to which these constrain UK trade arrangements after leaving the EU. The overall conclusion is that, in the longer term, the institutions of trade negotiations such as the world trade organisation WTO place little constraint on our policy choices; but there are difficult issues of transition and implementation, especially in relation to non-tariff barriers to trade and trade in agricultural products and services. These concerns, and the need for given and take in negotiations, mean that the replacement of our existing trade relations with new trade agreements, both with the EU and with other countries, cannot be undertaken quickly.

\section{a. Types of Trade Barrier}

\section{1. $\underline{\text { Tariffs }}$}

Tariffs are the best-known form of trade barrier. A tariff allows the government of an importing country to impose a tax on imports (either ad valorem, i.e. percentage of value, or specific, so many pounds per litre). Tariffs raise revenue, and also raise the price in the home market, protecting domestic producers who compete with the importers.

As well as tariffs, there are export subsidies (subsidising exporters). These cost the government revenue, but again protect home production at the expense of foreign competitors.

\section{Quotas/Voluntary Export Restraints}

A quota is a physical limit on the amount of a good that can be imported (for example, no more than 10,000 litres of whisky). In a market economy, the quota also raises the price to consumers at home, and protects local competitors. However, normally the revenue from the quota goes to the importing firm (unless the quota is rationed), so an importing government would usually prefer to impose a tariff, which raises revenue, rather than a quota.

Some countries (traditionally India during the years of the 'license Raj') also imposed quotas on exports. These tended to be allocated to well-connected companies, giving them rents at the expense of consumers and the overall economy. Economist Jagdish Bhagwati was well-known for his criticism of the license Raj.

A VER is an agreement between an importing country and a group of foreign exporters, that they would limit sales to the importing country. A classic case used to be the agreements between European and/or North American governments and Japanese car manufacturers over the years, to limit numerically car imports from Japan. This protects production in Europe/North America, and led to Japanese producers setting up local manufacturing plants in the importing countries. The VERs 
also led Japanese manufacturers to increase quality (and hence price) of the cars they exported to Europe/North America. VERs were outlawed by the WTO agreement of 1994, but are believed to continue to exist (just not being reported).

\section{Technical Barriers to Trade (TBTs)}

Countries often impose local standards and regulations to prevent goods which are dangerous, polluting or incompatible (for example with local electricity supply systems) from being sold. A degree of such protection is economically sensible in a world where externalities (such as pollution) exist, and where consumers may not be perfectly informed.

TBTs can impose an unintentional barrier to trade. In addition, a legitimate TBT can often be tweaked by a government as a form of covert protection: for example, Japan was known for many years for insisting on testing each batch of certain American electronic goods (while only testing Japanese firms every few months). In the 1980s, France insisted on all imported video players being tested at a centre in (inland) Poitiers. Arguably this had far more to do with protection of local producers, rather than banning dangerous video players. ${ }^{12}$

\section{Producer Subsidies}

Instead of taxing imports or subsidising exports, it is also possible to subsidise production (or to provide a producer with financial support to bear ongoing losses). This was very common during the economic cris es of the 1970s (for example with the subsidies to British Leyland or British Steel). Arguably the winding down of such support was a major way in which Britain's economy was liberalised during the 1980s. ${ }^{13}$

\section{Tax/Environmental competition}

Companies may be given tax breaks - either specific to one firm or general to all firms - in order to attract inward investment. Again, when countries distort their tax regimes strongly in order to attract mobile investment (while raising taxes on less mobile firms or people) this is arguably a serious distortion to trade.

\footnotetext{
${ }^{12}$ An important form of TBT is the use of Sanitary and Phytosanitary Standards (SPS): in the case of plants and livestock technical barriers have to be put in place at times, to prevent the spread of diseases. These usually consist of an absolute ban on certain products leaving one country (often a developing country) for another.

${ }^{13}$ In former Communist countries after 1990, a key element of the restructuring and privatisation process of industries was to 'harden' firms' budget constraints, so that they could no longer expect to be bailed out if they made losses.
} 
A parallel situation is where a country deliberately undercuts its rivals in environmental standards, setting up as a pollution haven.

\section{State purchasing policy}

Not all purchasing is done on the competitive market. Where governments (or large companies, often linked to the government) engage in discriminatory purchasing (favouring local producers), this again inhibits trade. Increased transparency of bidding and purchasing can be seen as a pro-trade policy, as can be policies to break up monopoly purchase arrangements.

There are a number of other issues, or more relevance to developing andemerging markets which can affect the costs of foreign trade. ${ }^{14}$ If and when the UK comes round to negotiating free trade arragnements with India, China, Brazil and other emerging markets these issues will also have to be covered in free trade negotiations.

\section{b. Global Trade Agreements: The World Trade Organization} The WTO was set up in 1995, as a result of the Marrakesh Agreement, and replaced the General Agreement on Tariffs and Trade, after the Uruguay Round of global trade negotiations.

The WTO currently has 164 members, while another 20 countries are observers.

There are 6 agreements associated with the WTO:

1. The Agreement establishing the WTO.

2. Agreements on Trade in Goods, and the Trade Related Investment Measures (TRIMS).

3. Services - the General Agreement on Trade in Services (GATS).

4. The Agreement on Trade Related aspects of Intellectual Property Rights (TRIPS).

5. Dispute Settlement (DSU)

6. Reviews of governments' trade policies.

\section{Principles of International Trade under the WTO.}

1. Non-Discrimination:

Border delays/bureaucracy. In developing countries, particularly, crossing a border can be a lengthy process, involving long queues, large amounts of paperwork and often bribes. Poor border infrastructure. Lack of currency convertibility. Barriers to Foreign Direct Investment. Poor legal and contracting systems in importing countries may deter foreign firms from investing. Lack of intellectual property protection is often cited as a problem for investors in China, for example.FDI may require the international movement of key staff, so restrictive visa systems will also constitute a barrier to FDI. 
a. The Most Favoured Nation (MFN) Principle. If country A offers concessions on trade in a certain product to one country, it must extend it to all WTO members.

b. National Treatment (NT). Any good which complies with a country's internal laws should be allowed access to the market, regardless of where it is produced.

c. Note that regional trade agreements are an exception to MFN. Meanwhile, NT is often seen as still allowing far too much scope for regulatory protection (hence the EU Single Market, and an increasing number of international agreements, supplement it with harmonisation or mutual recognition - see below).

2. Reciprocity. Countries trade concessions with each other.

3. Binding and enforceable commitments. If a country breaches a commitment later on, this can lead to the Dispute Settlement procedures being called upon.

4. Transparency - backed by periodic reviews of each member's policies.

5. Safety valves (there are exceptions to the above rules, for example to deal with animal or plant health emergencies).

\section{c. Regional Trade Agreements}

Free Trade Areas (FTAs)

An FTA consists of an agreement between a group of countries to abolish tariffs and quotas on trade between them. Hence, there is free trade within the FTA. However, countries in an FTA set their own tariffs and quotas with third party countries.

A few points about FTAs.

a) An FTA is not necessarily good for economic welfare. Consider, for example, NAFTA. The United States abolishes tariffs on manufactured imports from Mexico. However, importers from Brazil still pay tariffs. Hence, there is trade creation (trade between the USA and Mexico increases, allowing the two countries to specialise in the goods they are comparatively better at producing). But there is also trade diversion (Mexican exporters to the USA replace Brazilian ones, which may be lower cost).

b) Trade creation is likely to outweigh trade diversion (i.e. an FTA is 'good') if countries are 'natural trading partners' (i.e. they are situated close to one another), and if members specialise in relatively similar goods. Hence, an FTA of the USA and Canada (both wealthy countries) is less controversial than one including Mexico.

c) Because countries in an FTA set their own tariffs against third parties, this leads to problems. In theory, if Canada had low tariffs on Brazilian imports, but the USA had high tariffs, Brazilians could sell their produce to Canada and then reroute it to the USA. This could cause the FTA to break down. To avoid this happening, an FTA requires complex Rules of Origin. For example, Canadian exports to the USA require certification that more than $\mathrm{x} \%$ of the value added in production took place in Canada. Otherwise, they have to pay 
a tariff. $==>$ Rules of Origin mean that there is a bureaucratic cost to trade within a Free Trade Area.

d) Because a country in an FTA can set its own trade policy with third parties, membership of one FTA does not preclude membership of another FTA. For example, when Britain was in the old EFTA agreement (prior to joining the EEC), it was able to have its own free trade agreements with Commonwealth countries. These ended when we joined the EEC.

A Customs Union (CU).

Members of a CU abolish internal tariffs and quotas, but also charge a common external tariff. The EU is a Customs Union (among other things). ${ }^{15}$ Points about CUs include:

a) Trade within a CU is probably freer than that within an FTA, because there is no need to police rules of origin.

b) However, members of a CU cannot strike individual trade agreements with third countries. For example, a country cannot belong to a CU with one set of countries and an FTA with another set of countries (unless the $\mathrm{CU}$ as a whole joined the FTA). Britain had to abandon its trade agreements with Commonwealth countries when it joined the EEC (although the EEC did strike some trade deals with former colonies).

c) The same issues of trade creation and trade diversion apply to CUs as to FTAs. A CU is more likely to be beneficial if it is formed between 'natural trading partners' of similar income levels.

d) Because a CU coordinates external tariffs centrally, it has more bargaining power against the rest of the World. This means the $\mathrm{CU}$ has more power to act as a cartel, manipulating prices at the expense of third party countries.

e) On the other hand, a CU may have more bargaining power to force large countries to the table for a mutual trade deal.

f) Being outside a local CU can be disadvantageous, precisely because the CU has increased bargaining power against its neighbours.

d. Reducing non-tariff barriers through rules on market access

Trade negotiators have increasingly focused upon non-tariff barriers to trade (see previous section). A major impediment to trade is the application of rules that - intentionally or unintentionally - deny access to goods or services, or make such access expensive in terms of time, product modifications and legal/bureaucratic costs.

\footnotetext{
${ }^{15}$ Strictly, see https://en.wikipedia.org/wiki/European Union Customs Union some territories of the EU are not part of the customs union (e.g. Heligoland), some territories and countries outside of the $\mathrm{EU}$ are in the customs union (e.g. Monaco, Jersey)
} 
Some major disputes (for example between the USA and the EU on Genetically Modified Organisms) end up in the courts of the WTO. Usually, however, 'deeper integration' agreements aim at dealing with these disputes more swiftly.

One argument is that, if a company wants to export to a particular market, say the EU, it need only produce those goods it wants to export in a way which comply with EU rules. So, arguably, if Britain exports 15\% of its GDP to the EU, it need only apply EU regulations to $15 \%$ of goods it produces.

However, this overstates the degree of flexibility manufacturers or service providers have in producing for different markets. Moreover, a key issue is trust. If a regulator (say for the EU Single Market) does not trust that all goods produced within a particular country are compliant with EU standards, it will inevitably ask for far more regular testing and more exhaustive paperwork on any goods exported. This is potentially very costly. So in reality, if a country wants easy access for its exports to a foreign market, it needs a mutual agreement with its export market. This is particularly important for some services exports, where non-tariff/regulatory/red tape barriers are more important relative to other forms of protection.

Since the referendum, a number of contributors to the UK policy discussion have raised the possibility of obtaining 'access to the EU single market' under a free trade agreement with the EU, without being a 'member of the EU single market' e.g. like the EEA agreement for Norway and Iceland, hence obtaining free trade in goods and services with the EU but without accompanying obligations on free movement of people. The prospective free trade agreement with Canada, CETA, now agreed but subject to parliamentary ratifications, is put forward as an example of a country outside the EU obtaining such access.

In reality, for countries that are not members of the EU single market, access must be agreed on a product by product basis for different goods and services and through the weaker process of mutual recognition of standards rather than centralised harmonisation of standards. While there is certainly scope, should the UK not remain a member of the EU single market, for agreeing access without non-tariff barriers for many categories of EU-UK trade, this is not equivalent to membership. 


\section{Two approaches to agreement on market access: ${ }^{16}$}

a) Harmonisation of Standards.

Many of the rules within the EU Single Market are harmonised - in other words, laid down specifically by the Commission, and adopted by law in all member states. While this does result in a complicated set of rules, it is arguably a lot easier for firms to apply than if 28 states (plus Norway and Switzerland) all had their own, quite separate standards.

Harmonised standards have advantages. Disputes are avoided. One set of paperwork for companies wishing to sell to all EU and associated markets is much simpler than having several. Regulatory games between member countries are largely avoided.

Criticisms are that the system potentially gives excessive power to the Commission (and to industry groups advising the Commission), although the EU Parliament and Council of Ministers have oversight.

In addition, a harmonisation system results in a 'one size fits all' approach. Different countries have different priorities. Moreover, the harmonised regulations are often seen as part of an excessively bureaucratic culture. A study by the Department for Business, Innovation and Skills, found that EU regulation cost British industry around £8.6-9.4 billion in 2010, although the Taxpayers' Alliance and Eurosceptic Think-Tank Open Europe have higher cost estimates. ${ }^{17}$

\section{b) Mutual Recognition of Standards}

Rather than have a central body setting standards for all countries, it can be simpler for countries to agree to accept each other's standards as acceptable for access. If goods produced in country A meet the local regulator's standards, they are deemed fit for sale in country $B$, as long as goods produced in B to B's regulator's standards are likewise accepted in A.

In the case of plant diseases, say, this would mean two countries accepting that the other's procedures for disease prevention are adequate. In the case of health and safety, it would mean accepting that each country has satisfactory procedures for ensuring that goods are not carcinogenic.

\footnotetext{
${ }^{16}$ For more details, see Maskus and Wilson's (2001) World Bank study: Quantifying the Impact of Technical Barriers to Trade, Michigan University Press.

${ }^{17}$ A comparison of estimates is available on https://fullfact.org/news/cost-eu-can-we-count-expressestimates/. 'Cost of the EU: Can we count on Express estimates?'

A report by Open Europe on the 'Top 100 costliest EU regulations' is available on http://openeurope.org.uk/intelligence/britain-and-the-eu/100-most-expensive-eu-regulations/.
} 
Mutual recognition agreements can be quicker to reach than harmonisation, and are also less centralised, giving more scope to individual states to choose their own priorities. On the other hand, mutual recognition requires a dispute-settling authority independent of the countries' governments. This is the basis of the Trans Pacific Partnership and Canada-Europe Trade Agreement agreements, and of the proposed Transatlantic Trade and Investment Partnership agreement. Arguably these agreements, while more decentralised, are also less democratic than the traditional EU harmonisation approach, since they hand ultimate power to 'unelected judges'.

A number of economic studies have analysed whether there are biases in standard-setting under mutual recognition: in particular, whether a 'race to the bottom' in standards is likely to occur. While early studies found this was unlikely, more recent papers have found that, in the cases of i) environmental pollutants and ii) where a good is overwhelmingly exported in one direction, there will indeed be a bias towards undermining standards. ${ }^{18}$ In short, compared to the EU approach of harmonisation ${ }_{2}$ mutual recognition which will be required in any future deep and comprehensive trade agreements signed by the UK, may tend to favour corporate interests rather than environmental or health and safety lobbies.

\section{Existing trade arrangements with the EU.}

We can distinguish the EU's various trade agreements, in approximate order of closeness of integration as follows:

1. Full membership of the Single Market. Implies free movement of goods, services, capital and labour.

2. Membership of the European Economic Area (Norway, Iceland and Liechtenstein). These adopt EU Single Market legislation, except for certain exclusions (agriculture and fisheries).

3. Switzerland. Strong participation in the Single Market subject to bilateral agreements but remaining outside of the Customs Union

\footnotetext{
${ }^{18}$ See for example Costinot, A. (2008). A comparative institutional analysis of agreements on product standards. Journal of International Economics, 75(1), 197-213; and Edwards, T. H. (2009). Tariffs, Horizontal Regulatory Standards and Protection against Foreign Competitors. Global Economy Journal, 9(2).
} 
4. Turkey has a separate Customs Union agreement with the EU (since 1995), but is not a full member of the Single Market. Its longstanding application for accession is showing few signs of progress

5. Deep and Comprehensive Free Trade Agreements or DCFTA with Ukraine, Moldova and Georgia (2014).

6. Deeper Trade Agreements that go substantially beyond WTO (e.g. with South Korea, 2011,deals with Canada and with Japan are now at final stage of agreement. A TTIP with the US, is also being pursued, thought the atitudes of the current US administration put this in doubt.).

A DCFTA means membership of a free trade area with the European Union (no tariffs with the EU), though DCFTA members are able to set their own external tariffs with third parties, including joining other FTAs. In the cases of Ukraine, Moldova and Georgia, membership of a DCFTA does not, therefore, preclude them from forming FTA agreements with Russia or other CIS countries, although these countries could no longer join the Eurasian Economic Union (Russia, Belarus, Kazakhstan and Kyrgyzstan).

Since it is a FTA, imports from Ukraine, Moldova and Georgia will still be subject to Rules of Origin, which is in effect a barrier to free movement of goods and services with Europe. There is no commitment to free movement of people. However, the three DCFTA states have undertaken to implement all EU product market rules - in return for which there will be no further market access barriers to their exporters selling to Europe. Note that moving from old GOSTs to EU standards will take time and be costly, but this will improve export prospects for these countries across the World (since their exports will be seen as complying with the standards of advanced Europe).

There are a number of aspects of the DCFTAs which could be attractive to the UK in determining its future trade relations with Europe: (i)No market access barriers; (ii) No tariffs with Europe; (iii) No commitment to free movement of labour; and (iv) Freedom to sign FTAs with other countries outside Europe.

However, UK exporters would face rules of origin red tape. Britain would be subject to rules set by the EU Commission with no say. Some companies (big polluters, for example) would undoubtedly campaign against a DCFTA. There is also no guarantee that Britain could achieve a DCFTA with the EU without making considerably more concessions than Ukraine, Moldova or Georgia have done. There may be difficulties in achieving WTO approval for any such agreement.

\section{d. Does the WTO constrain or help UK trade policies after Brexit?}

We can complete this section with a brief discussion of the extent to which the WTO rules may affect UK trade arrangements after Brexit. Much of this material is taken from the discussions at our Dec 2016 conference, both the presentation by Alan Winters and the closing panel discussion. But the summary and interpretations 
provided here are own. We refer to our suggestions for further reading, for a fuller account of these issues.

Perhaps the most important point is that membership of the WTO will after Brexit be the foundation for all our trade relations. Moreover it will be difficult to have serious negotiation with other countries outside of the EU until the relationship with the EU is more clarified (which as we argue is likely to take some years).

The UK is a member of WTO, with rights and obligations that at present are determined and communicated by the EU on behalf on the UK. The WTO offers a well understood process, referred to as rectification, through which these rights and obligations can be restored to the UK. The UK will make formal proposal. This would then be submitted to WTO; the director-general circulates this and other countries have three months to object. If there are no objections after three months, this is formally accepted within the WTO schedule.

There are two reasons why non-EU countries might have objection. First they may feel that a tariff of say $10 \%$ with the UK and separately of $10 \%$ with the EU is not quite the same thing as a $10 \%$ tariff when the UK is a member of the EU. Secondly there may well be concerns about agriculture, which is always a difficult challenge in trade negotiations. The most obvious problem relating to agriculture arises with what are known as 'tariff rate quotas' or TRQs. These reduces the amount of tariff paid, for a given country exporting to the EU upto an agreed quantity of exports. A prominent example is lamb from New Zealand, where a little over 200 tonnes can currently be exported tariff free each to the EU.

The key issue is, how, post rectification will TRQs be determined and allocated between the UK and to EU? The outcome will then depend, critically, on future expectations for UK policy. If the UK, as some advocate, is expected to eliminate all tariffs on agricultural imports then any transfer of TRQs to the UK, rather than to the rest of the EU, will become valueless. On the other hand TRQs transferred to the EU which are then not fully used are also going to be resisted.

Other issues that may affect rectification are subsidies (though unlikely to be a major issue because EU rules are much more constraining than WTO rules, most opportunities for substidy under WTO rules are not fully utilised); and rules on government procurement where devolvement to UK will be a cause of concern if there is any reason to believe that the UK will become more protectionist than it is under existing EU procurement rules.

Finally the implications of WTO membership for a future deep and comprehensive free trade agreement between the UK and the EU need to be kept in mind. While WTO rules do support agreement on standards and regulations, for example GATT article XXIV supports conformity assessment procedures for mutual recognition, for example it recommends "Members shall accept [equivalent] sanitary or phytosanitary measures of other Members...". But while the principal is clearly stated, there is no 
formal mechanism (equivalent to the European Court of Justice in enforcing the rules of the European Single Market) so in practice substantial regulatory and product standard barriers can remain unaddressed.

Another key point here is how little prescription there is in the WTO agreements on reducing barriers to trade in services. Here we very much agree with the assessment of a UK Trade observatory briefing paper: ${ }^{19}$ "The EU Single Market for services may be imperfect but it goes a long way towards facilitating the exchange of services amongst members. Thus, Brexit will almost surely be associated with a deterioration in market access conditions for UK providers; however, the extent of that change is difficult to gauge for two reasons. First, applied services trade policies in the areas of cross-border trade, investment, and movement of people are typically more liberal than what the WTO's General Agreement on Trade in Services (GATS) commitments would prescribe. Second, unlike for goods trade, there is no uniform EU services trade regime for suppliers from outside the EU. Hence, upon leaving the EU access to EU markets for UK service providers is likely to deteriorate in a way that differs across EU member states, sectors, and modes of supply."

What this quotation highlights is the challenge of replacing the benefits of the Single Market for trade in services. This is not to say that the UK cannot successfully engage in services trade outside of the EU, it already does especially in financial services and other business services. But services exports to the EU make an important contribution to UK trade and, unless and until a deep and comprehensive free trade agreement between the UK and the EU covering services is in place once any interim post-Brexit membership of the Single Market comes to an end, then UK services exports to the EU could be substantially reduced.

\section{e. A deep and comprehensive EU-UK Free Trade agreement?} We complete this section by drawing together some 'threads' of the previous discussion both to make the case for the critical importance of a deep and comprehensive EU-UK Free Trade agreement and the substantial challenges involved in having this successfully negotiated.

A first point to make is that there (despite the fantasies of many journalists) there is no 'off the peg' arrangement for EU-UK trade arrangements post-Brexit. We cannot just copy Norway (membership of the EEA except fishing), Switzerland (a sector by sectgor agreement), Turkey (customs union and some additional access to European markets e.g. in motor car manufacture). What ever replaces our membership of the Single Market will have to be tailored to the specific UK situation

${ }^{19}$ Borchert, I. (2016). Services trade in the UK: what is at stake? (Briefing Paper No. 6). Brighton, UK: University of Sussex. Retrieved from http://sro.sussex.ac.uk/65675/ 
and to the various interest groups both in the UK and in the EU that will be affected by the trade agreement.

The severe challenges of negotiating agreements for agriculture cannot be avoided, both in terms of external tariffs (taking account of the interests of many third countries currently exporting to the UK) and in terms of standard setting.

While departure from the Customs Union seems a comparatively 'easy win' in terms of establishing greater freedom for the UK to conduct our own trade arrangements with third countries, this raises the difficult question of customs inspections at the Northern Ireland- Republic of Ireland border. A solution is needed that keeps all parties happy.

When leaving the Customs Union, special arrangements will still be needed to ensure that leaving the Customs union does not then result in an unacceptably high regulatory compliance burden in order to enforce rules of origin (the EU $n$ when these are relatively low).

The really difficult issues though arise in relation to non-tariff barriers, establishing on a sector by sector basis new arrangements that replace UK membership of the Single Market and appropriate enforcement mechanisms that support mutual recognition of standards and regulations and so avoid the need for extensive checks at the EU-UK frontier. In order to achieve this in a timely fashion, there would seem to be little alternative to accepting the jurisdiction of the European Court of Justice, in order that there is relatively quick agreement that in turn unlocks the economic benefits of the UK having freedom to make its own agreements on non-tariff barriers with third countries.

Finally it must be emphasised that all these issues will need to be nailed down before there is a final agreement. Nothing is agreed until everything is agreed. Recalling that there are 27 countries remaining in the EU, each with their own specific interests in international trade, it is inconceivable that this massive negotiating challenge can be undertaken in a few months. Judging by the experience of the Canadian and Japanese free trade arrangements with the EU, this will take several years. Assuming good will and a constructive approach on both sides (which means giving up the rather unhelpful political rhetoric that has emerged since the Brexit referendum) this can perhaps be done in five years. To assume much less would seem to be naively optimistic. Nor can the need for such a comprehensive agreement be ignored, unless there is political appetite to undergo a sharp decline in UK living standards (judging by the projections summarise in Section 2 of around 5-8\% decline in UK GDP) and, moreover, mudding the water for similar trade agreements with third countries, in order to achieve a rapid but costly Brexit. 


\section{Descriptive statistics for UK international trade.}

This section presents a table and number of charts, assembled from various sources, illustrating some prominent features of UK international trade.

Table 5 below shows a breakdown of UK's trade with Europe and with NonEuropean countries. Using these 2014 figures, UK exports amounted to 816 UD\$ bn. of which 511 US\$ bn. were in goods and 305 UD\$ bn. in services. European countries then accounted for more than half of UK exports in both goods and services, 291 and 160 US\$ bn., respectively.

Table 5: Summary of UK external trade in 2014

\begin{tabular}{lrrr}
\hline VARIABLES (US\$ bn) & Europe $^{20}$ & $\begin{array}{c}\text { Non- } \\
\text { Europe }\end{array}$ & \multicolumn{1}{l}{ Total } \\
\hline Exports of Services & 160.2 & 144.7 & 304.9 \\
Exports of Goods & 291.9 & 219.3 & 511.1 \\
Total Exports & 452.0 & 364.0 & 816.0 \\
Imports of Services & 112.2 & 71.8 & 184.0 \\
Imports of Goods & 421.1 & 273.3 & 694.3 \\
Total Imports & 533.2 & 345.1 & 878.3 \\
Total Net Trade & -81.3 & 29.1 & -52.1 \\
Net Trade in Goods & -129.2 & -43.8 & -173.0 \\
Net Trade in Services & 48.0 & 72.9 & 120.9
\end{tabular}

Note: This table shows UK's trade volumes in Goods and Services in 2014 (US\$ bn.) for European and Non-European countries. Source: Comtrade database, calculations by authors.

These figures, suggesting that Europe is more important than the rest of the world as an export market for the UK, contrast with widely cited 2015 data from the ONS showing relatively larger exports of goods and services from the UK to outside of the EU compared to exports to the EU. This discrepancy reflects several factors: first the

\footnotetext{
${ }^{20}$ Albania, Andorra, Azerbaijan, Austria, Armenia, Belgium, Bosnia Herzegovina, Bulgaria, Belarus, Croatia, Cyprus, Czech Rep, Denmark, Estonia, Finland, France, Georgia, Germany, Greece, Hungary, Iceland, Ireland, Italy, Kazakhstan, Latvia, Liechtenstein, Lithuania, Luxembourg, Malta, Montenegro, Netherlands, Norway, Poland, Portugal, Romania, San Marino, Serbia, Slovakia, Slovenia, Spain, Sweden, Switzerland, Turkey, Ukraine
} 
importance of UK exports to other European countries not in the EU, notably Switzerland and Norway, second the sharp appreciation of the dollar relative to the Euro in the course of 2014, third the exclusion of banking and of transport, travel and tourism from the ONS statistics for 2015, fourth somewhat higher growth between 2014 and 2015 of output and imports in countries outside of Europe than in Europe.

Table 5 also reveal that in 2014, UK imports of 878 US $\$$ bn., of which 533 US\$ bn. were from Europe and 345 US\$ bn. from the rest of the world. The UK had an overall trade deficit of about 52 US $\$$ bn. in 2014, consisting of a trade surplus in services of 121 US $\$$ bn. and a trade deficit in goods of 173 US $\$$ bn.

\section{UK Trade in Goods}

We next look at the breakdown of UK trade in goods, by individual country and sector. Figures 3 to 6 show country destinations, showing that a small number of destinations account for a relatively large proportion of overall trade (outside of Europe the US and China, the other major countries of Asia, and some of the large oil-exporters from the middle east; within Europe the larger members states in the EU and also Switzerland). This is the case both for exports and for imports.

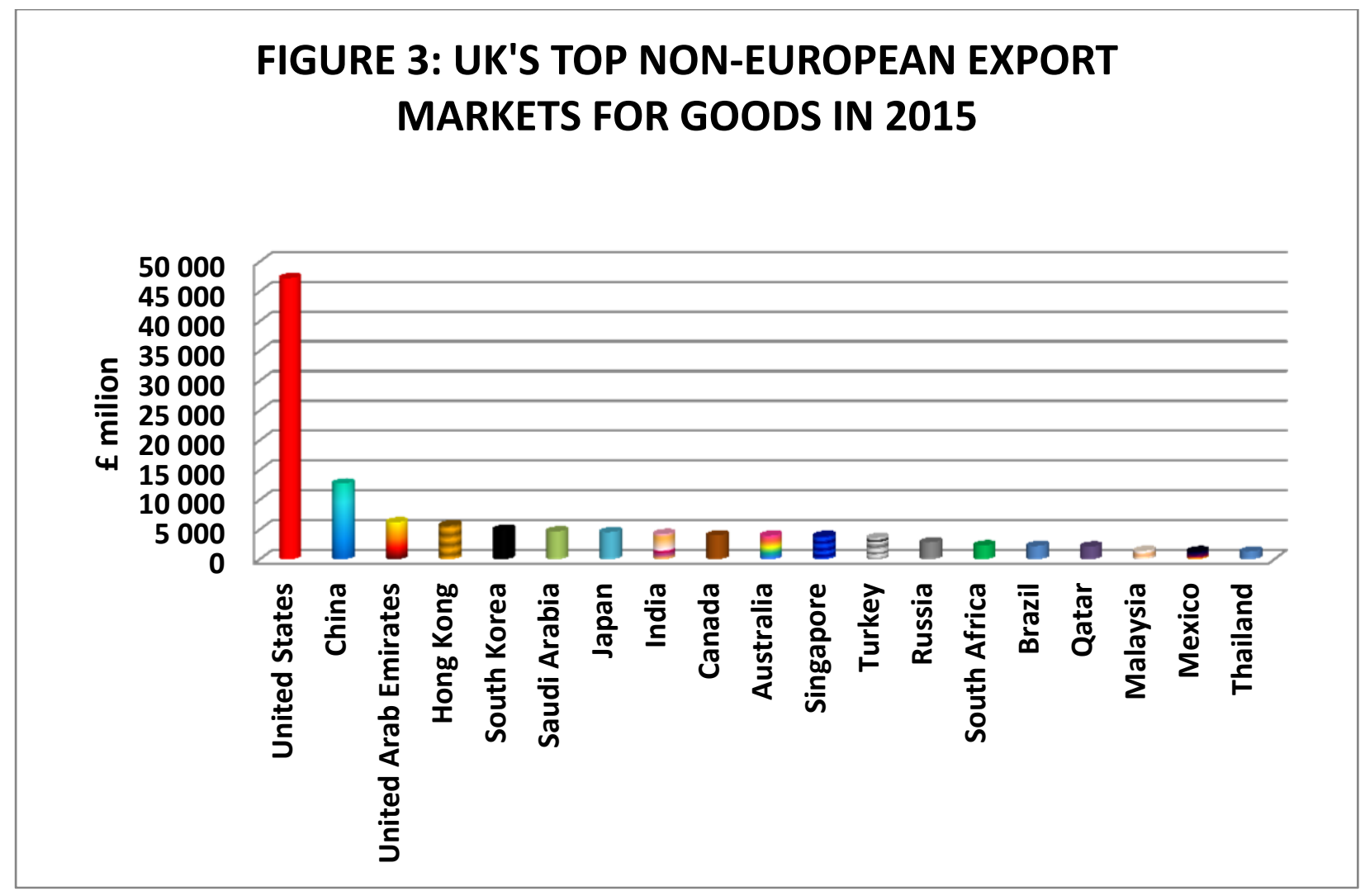

Note: Author calculation using the Office for National Statistics (ONS) data. 


\section{FIGURE 4: UK'S TOP EUROPEAN EXPORT MARKETS FOR GOODS IN 2015}

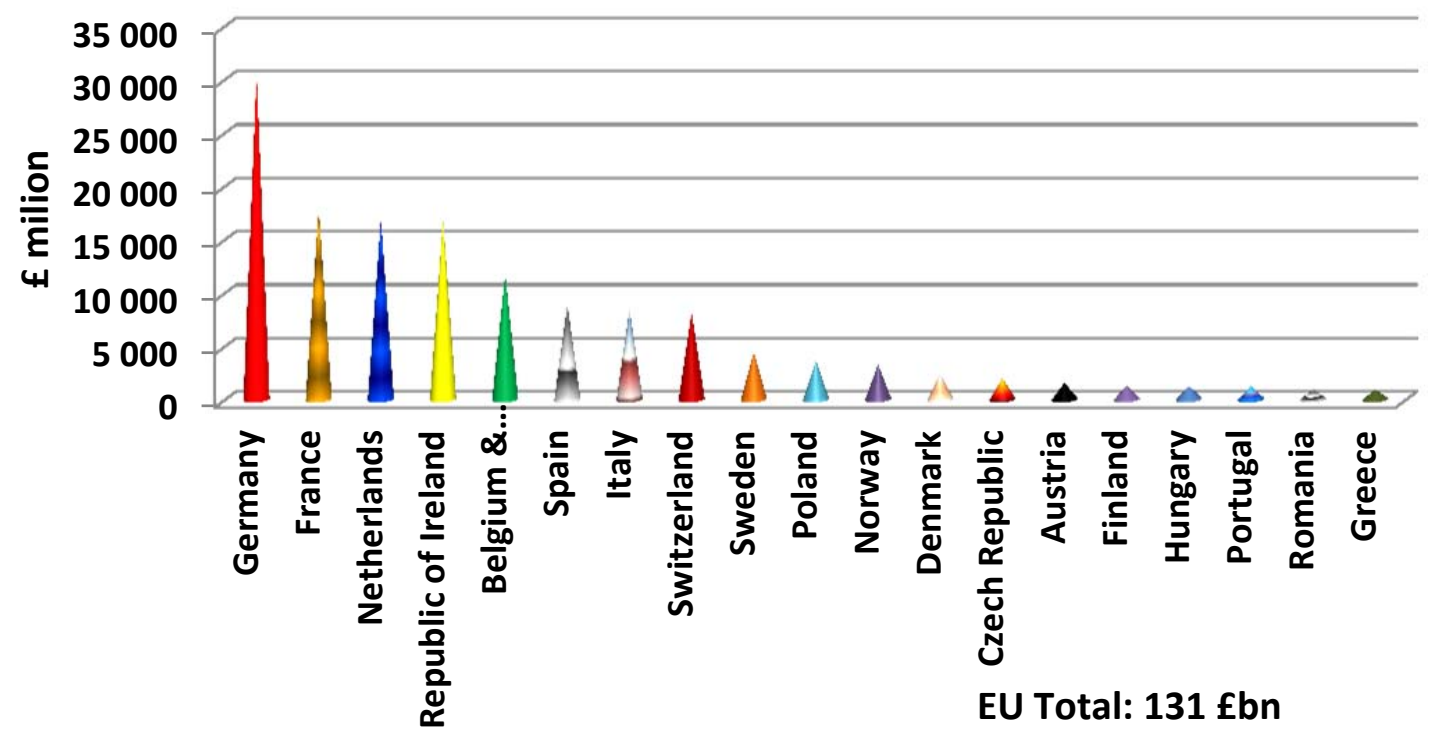

Note: Author calculation using the Office for National Statistics (ONS) data.

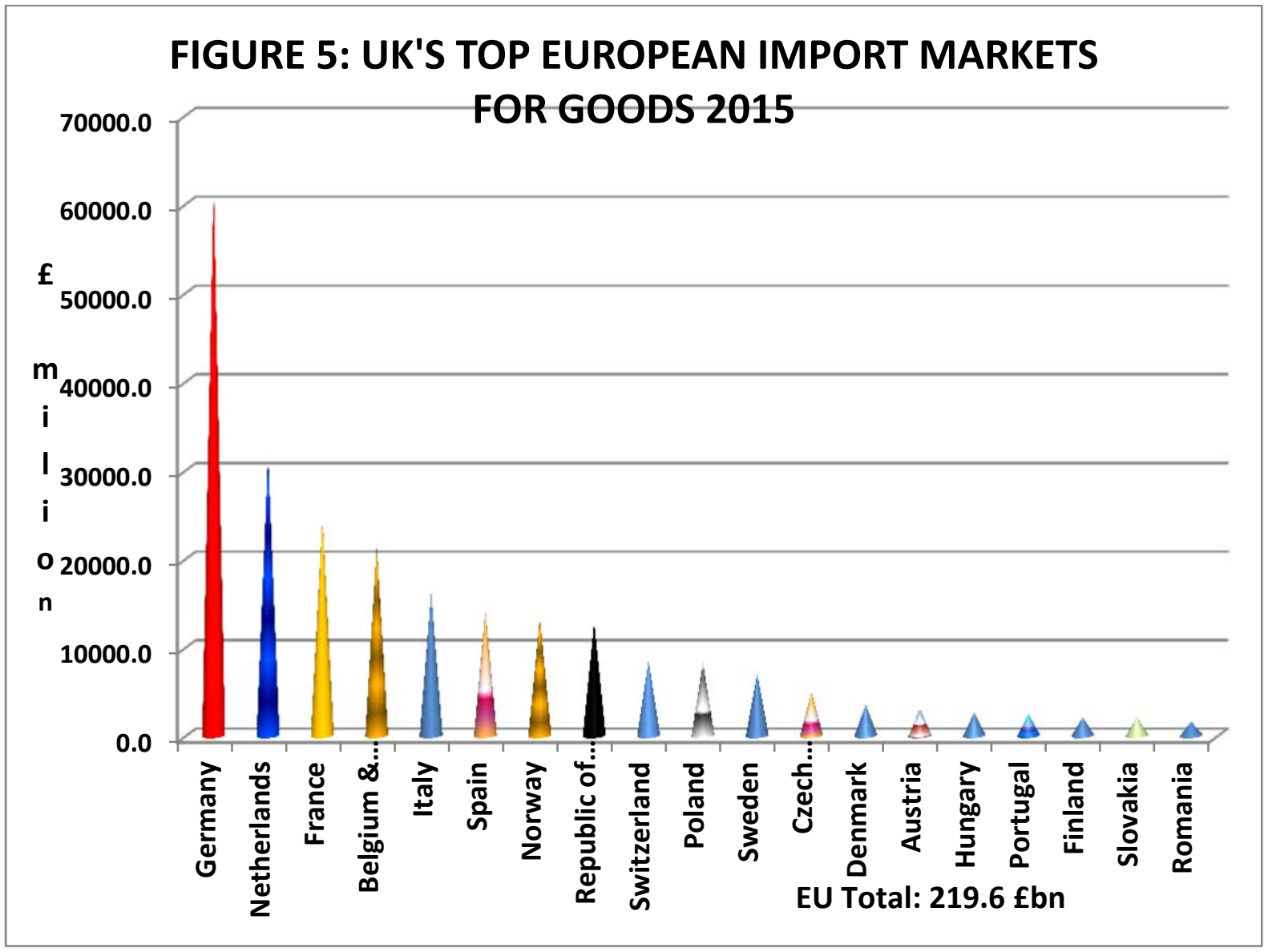

Note: Author calculation using the Office for National Statistics (ONS) data. 


\section{FIGURE 6: UK'S TOP NON-EUROPEAN IMPORT MARKETS FOR GOODS IN 2015}

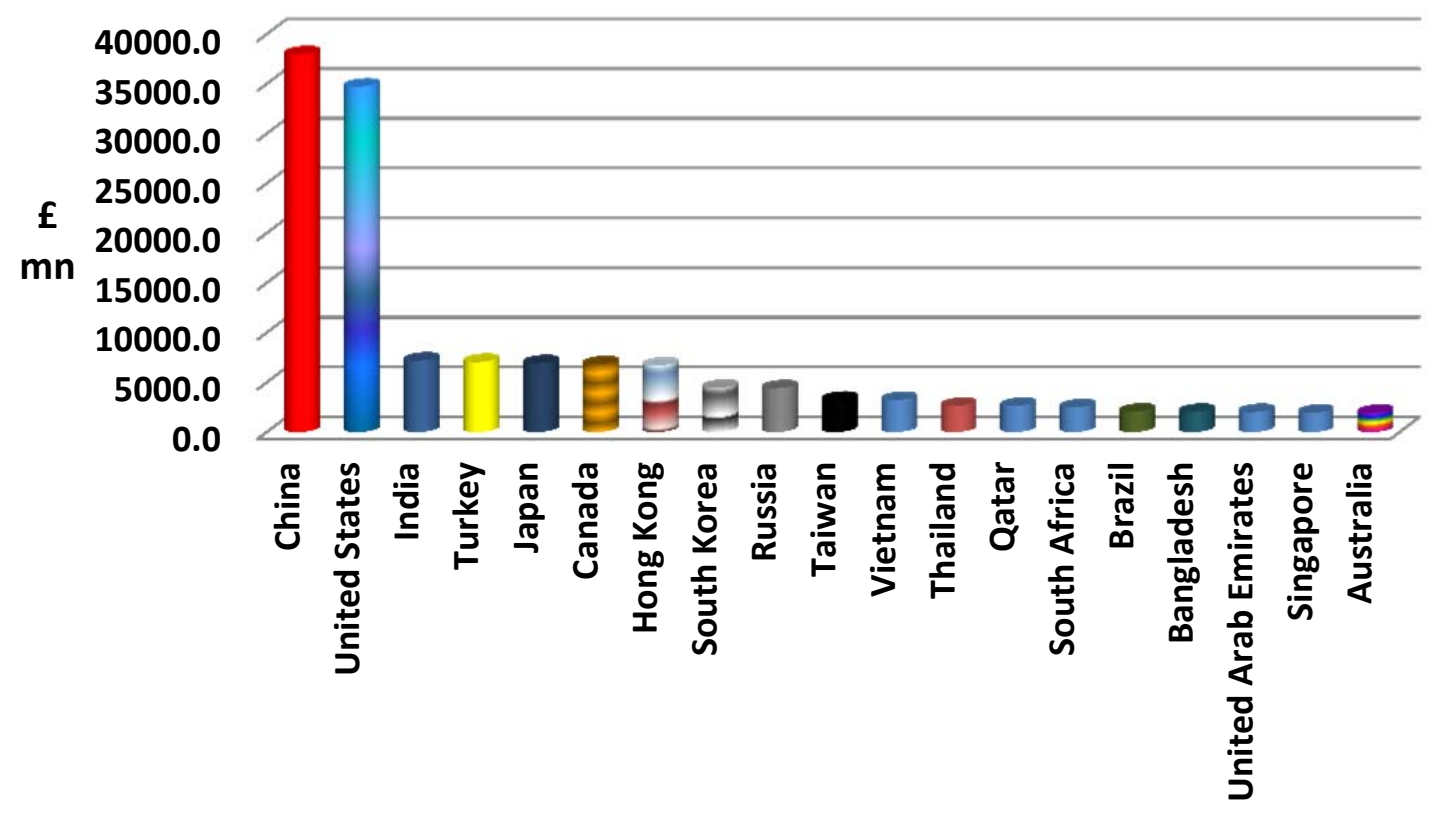

Note: Author calculation using the Office for National Statistics (ONS) data.

Figures 7 and 8 show a breakdown of both imports and exports of goods, by major industries in 2015. Both imports and exports are dominated by manufactured goods, with a concentration in relatively few categories of manufactured goods: electrical and mechnical machinery; cars, aircraft and other road vehicles, and medicines, pharmaceuticals and chemicals. Combined together these categories of manufactures account for $54 \%$ of total imports and $59 \%$ of total exports. 


\section{FIGURE 7: UK's Major Goods Imports}

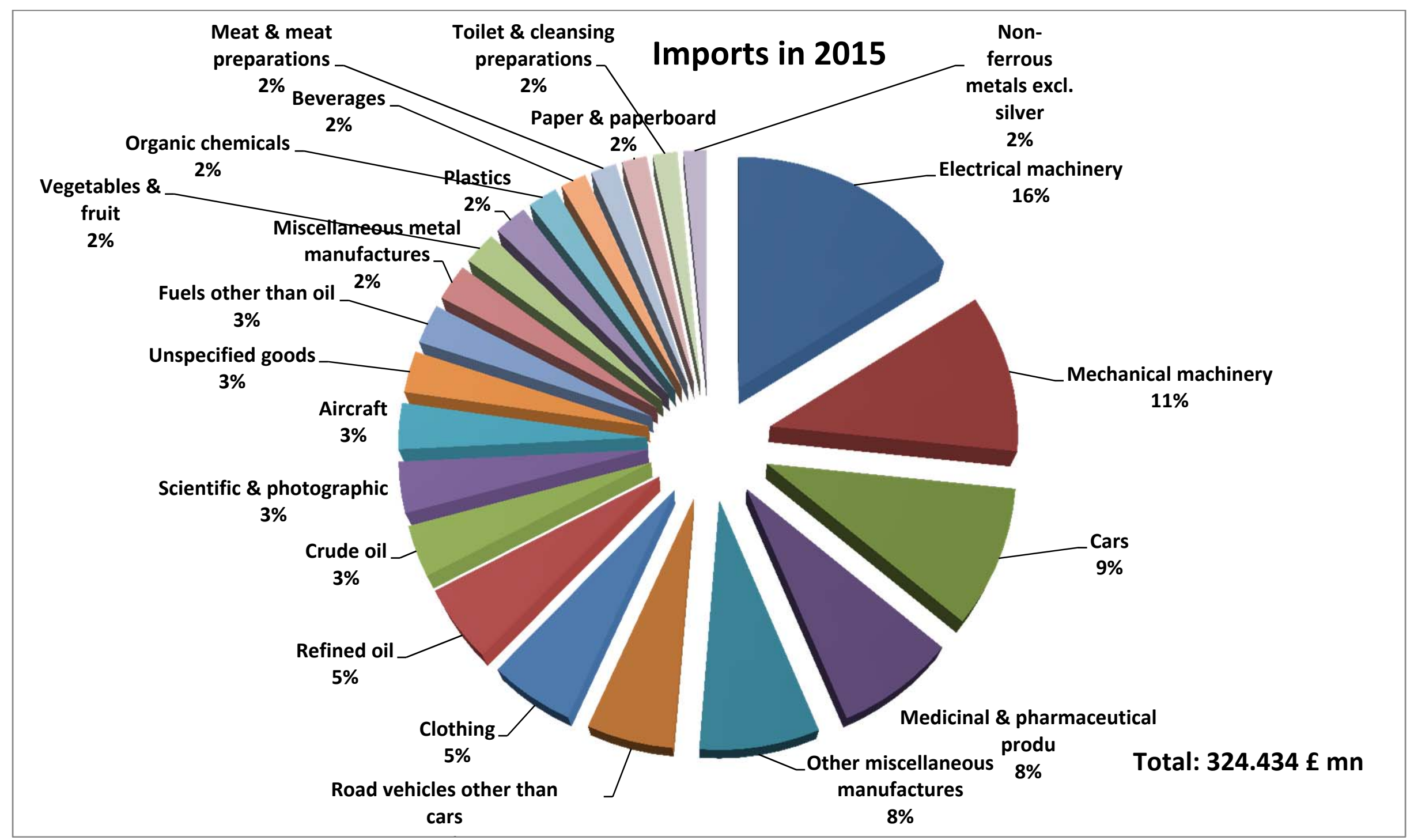

Note: Author calculation using the Office for National Statistics (ONS) data. 


\section{FIGURE 8: UK's Major Goods Exports}

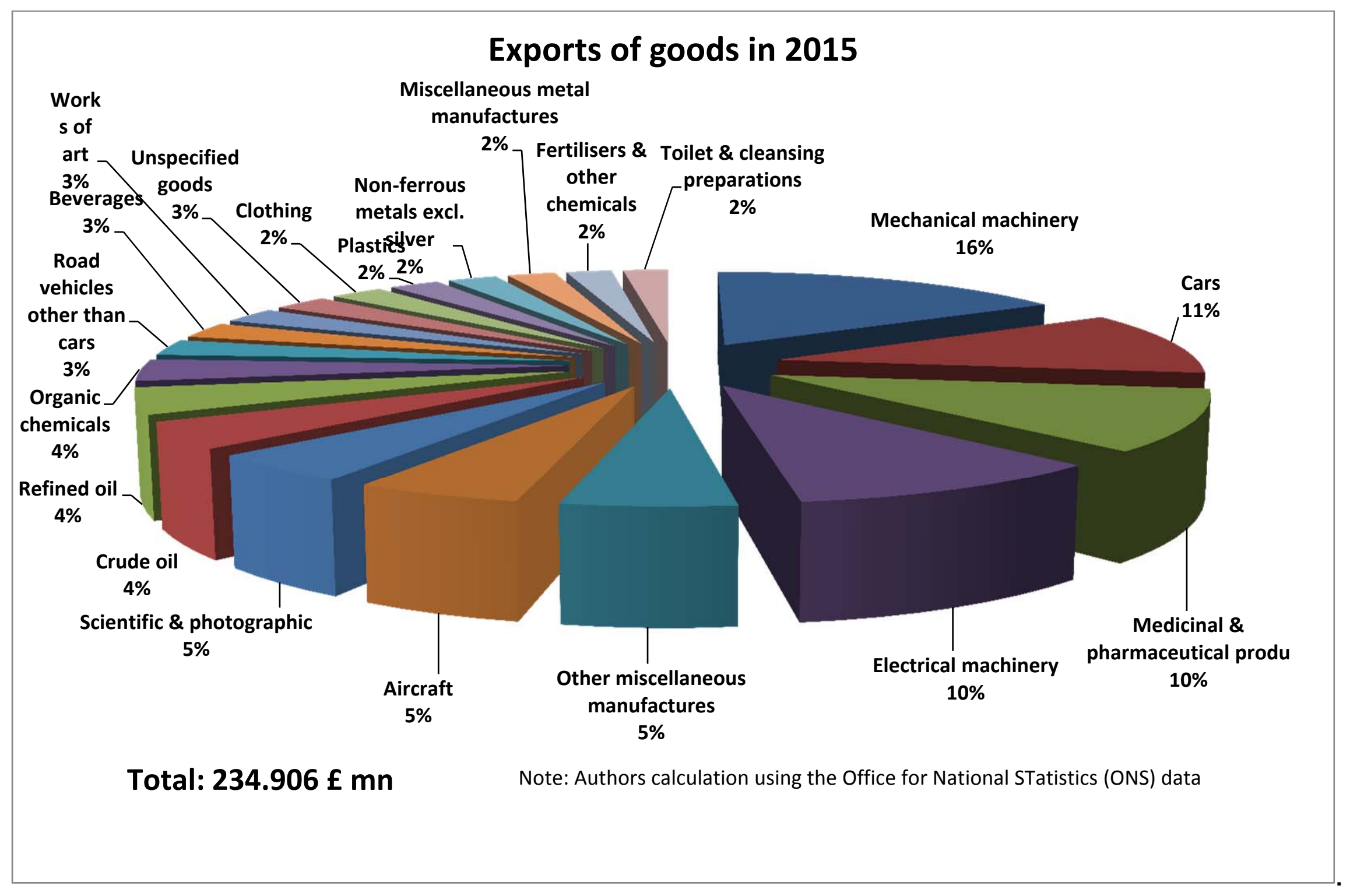


UK Trade in Services

Figure 9, taken directly from the 2016 Pink Book breaks down UK services exports.

Figure 9: ONS 2016 Pink Book (Figure 6): UK exports of services, 2015

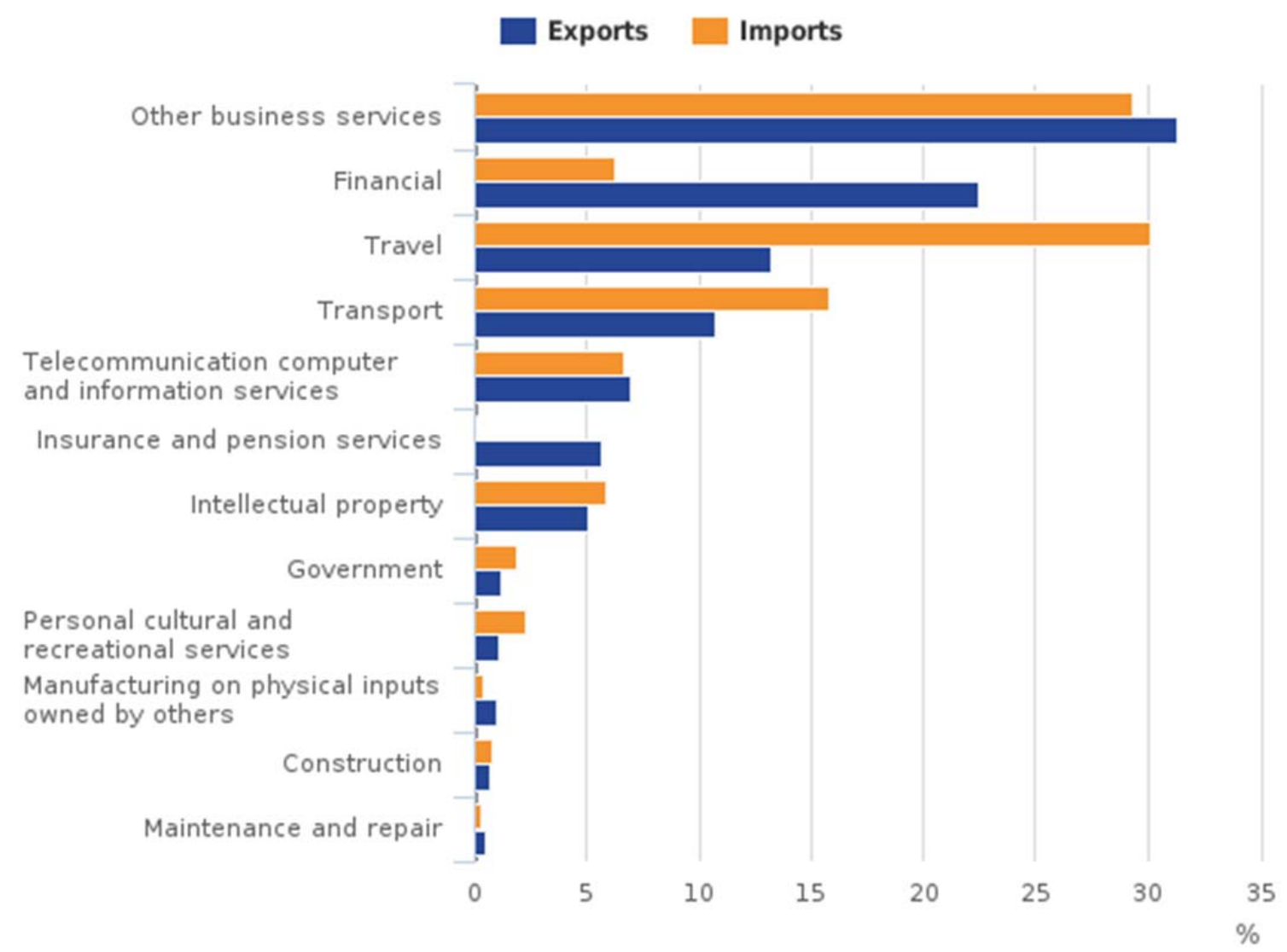

Compared to the UK's export of goods, there is a relatively large variety of services exports. Important sub-categories within other business services include: Advertising, market research and public opinion polling services; Architectural services; Accountancy, auditing, bookkeeping and tax consulting services; Business management and management consulting services; Engineering Services; and Scientific and other technical services including surveying (This statement is based on the more detailed breakdown of 2014 data in Table C5 of the Annex to the January 2016 ONS publication "International Trade in Services: 2014").

Figures 10 and 11, show a breakdown of services exports and imports by country for 2014. As in the case of goods trade, most exports and imports are with relatively few destinations, the USA, the major countries of Europe including Switzerland and Japan; but with relatively less trade with China and other middle income countries 
in Asia (the UK services exports to Austrlia are approximately double those to China). A relatively large volume of imports of services from India, which we believe refelect outsourcing of IT and other business activities.

\section{Export value added}

Figures 12, 13 and 14 report sectoral export value-added for 2011, in US\$ mn., using the GTAP database (a harmonised international trade database that also includes that allows calculation of the earnings of each sector after netting out imported intermediate inputs). Compare Figure 12 with the first two rows of our Table 3 which shows that the gross value of manufactured exports (511 US $\$$ bn.) is around $70 \%$ larger than the gross value of service exports (304 US\$ bn.). Netting out imported intermediate inputs to obtain a figure for value added for the UK economy, Figure 12 shows that in terms of income generation exports of services -- at a little over \$100 US\$ bn. - are a little larger than exports of manufactures. This reflects the complex international supply chains in modern manufacturing.

Figure 13 presents a more detailed breakdown of the same value added data, for individual subsectors of services. Around $60 \%$ of the value added in UK exports of services are in sector 54 business services n.e.c.) Sectors 52 and 53,, financial services n.e.c. and insurance account for a little over $20 \%$ of value added in UK exports of services.

Figure 14 presents a similar breakdown of value added data for individual manufacturing sub-sectors. Over $70 \%$ of value added in manufacturing exports is accounted for by five sectors, in order of importance: 33 (Chemicals-rubber, and plastics), 41 (Machinery and equipment n.e.c., 38 (Motor vehicles and parts), 39 (Transport equipment n.e.c) and 40 (Electronic equipment).

\section{Tariffs}

Figure 15 reminds us that the period since the ending of World War II has been one of historically low tariffs, which as a trade-weighted average over all sectors, were reduced to nearly negligible levels through multilateral agreement (GATT and then the WTO). Figure 16 and 17 show tht that some relatively high tariffs remain for trade in some particular goods with specific destinations, e.g. (re)export of rice to Japan and CIS countries. 


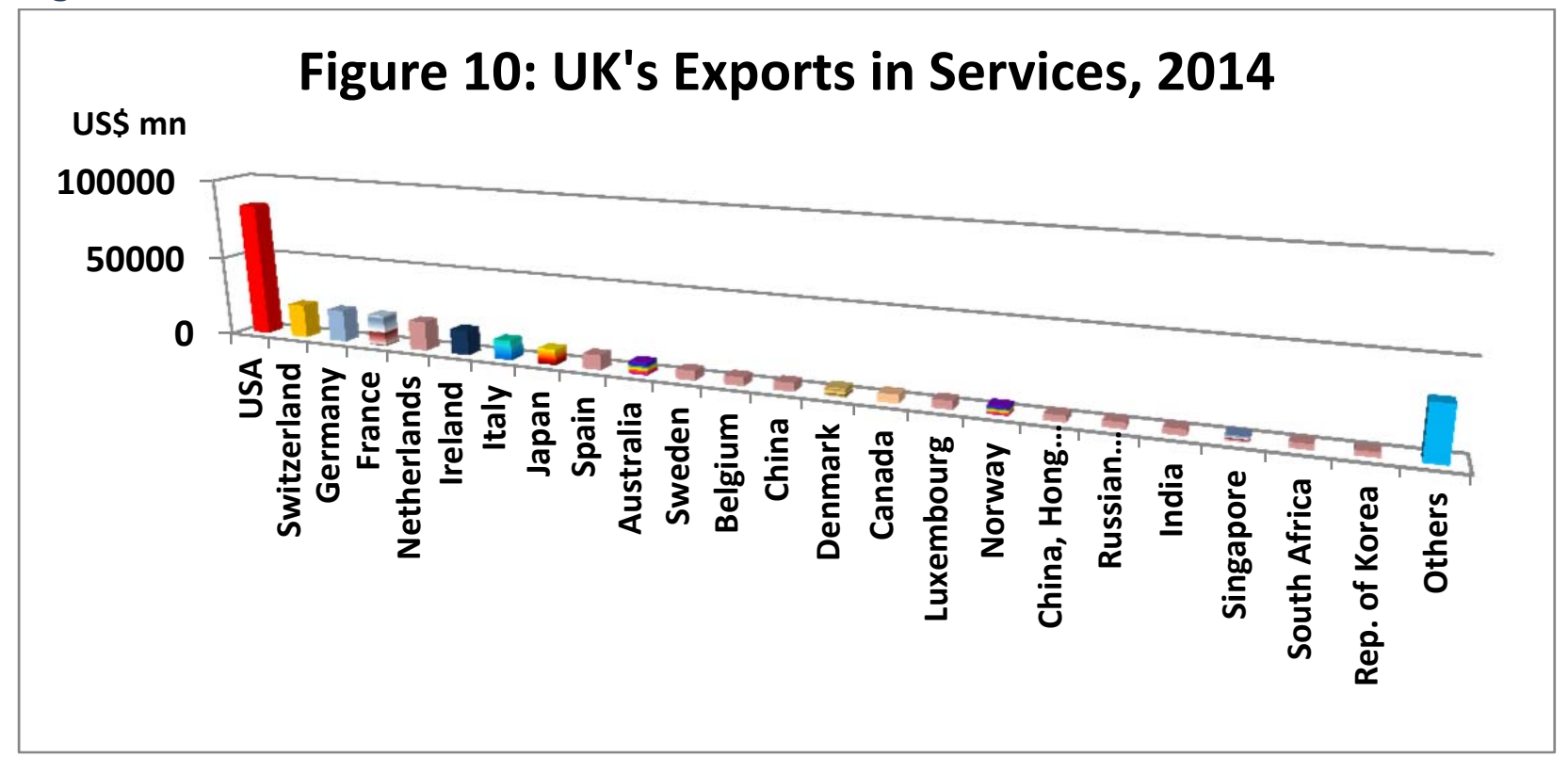

Note: Author calculation using Comtrade database. These include financial sector and travel services.

Figure 11: UK's Imports of Services, 2014

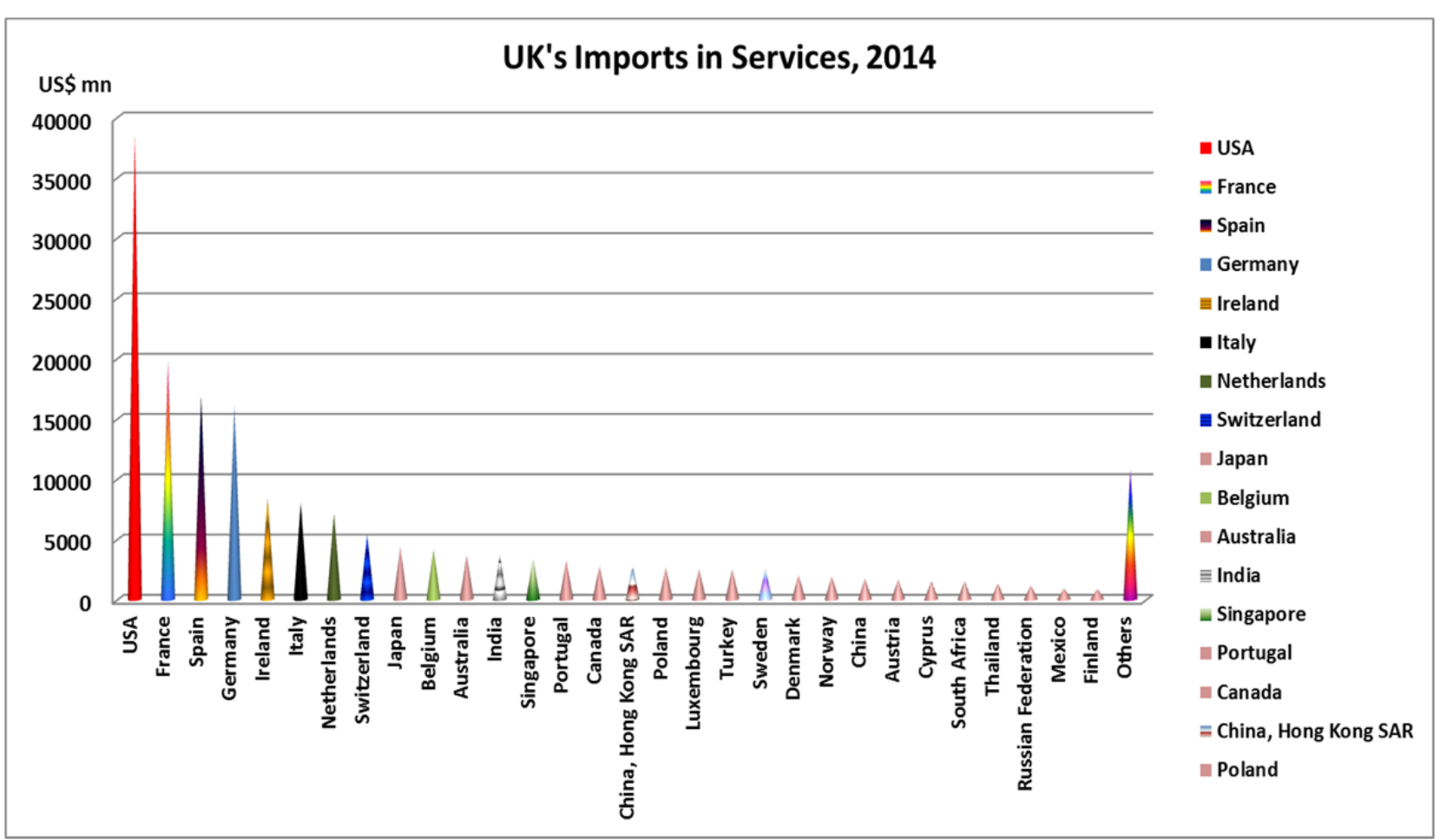

Note: Author calculation using Comtrade database. These include financial sector and travel services 


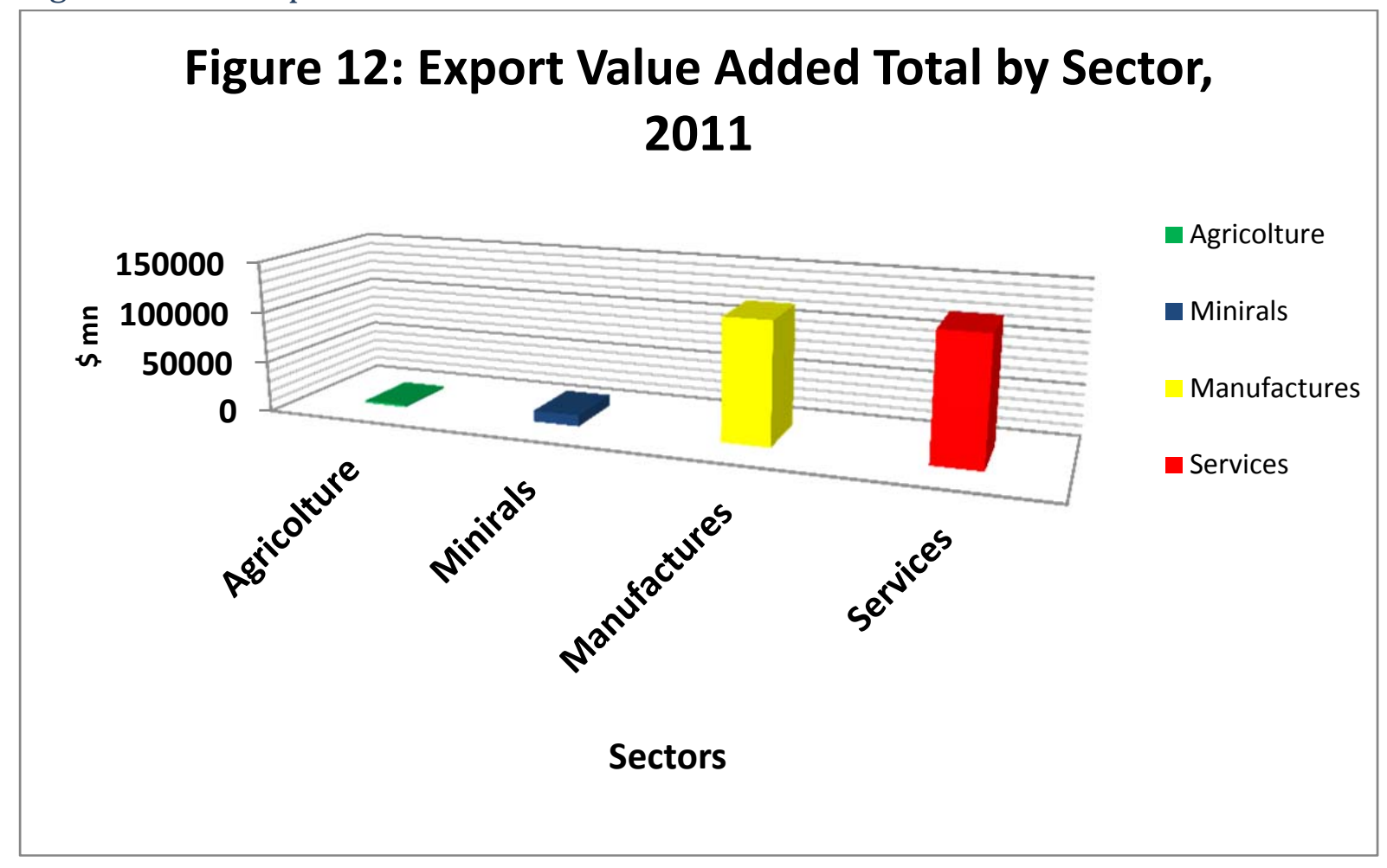

Note: Author calculation using Gtap 2011 data for agriculture and minerals ${ }^{21}$. manufactures $^{22}$, and services. ${ }^{23}$

\footnotetext{
${ }^{21} 1$ Paddy rice, 2 Wheat, 3 Cereal grains, 4 Vegetables- fruit-nuts, 5 Oil seeds, 6 Sugar cane- sugar beet, 7 Plant-based fibers, 8 Crops, 9 Bovine cattle-sheep and goats- horses, 10 Animal products, 11 Raw milk, 12 Wool- silk-worm cocoons, 13 Forestry, 14 Fishing.

${ }^{22}$ Electricity 43, Gas manufacture distribution 44, Water 45, Construction 46, Trade 47, Transport nec 48, Water transport 49, Air transport 50, Communication 51, Financial services nec 52, Insurance 53, Business services nec 54, Recreational and other services 55, Public Administration Defense -Education- Health 56, Dwellings 57

${ }^{23} 19$ Bovine meat products 20 Meat products nec, 21 Vegetable oils and fats 22 Dairy products, 23 Processed rice, 24 Sugar, 25 Food products nec, 26 Beverages and tobacco products, 27 Textiles, 28 Wearing apparel, 29 Leather products, 30 Wood products, 31 Paper products- publishing, 32 Petroleum- coal products, 33 Chemical ${ }^{*}$-rubber,-plastic products, 34 Mineral products nec, 35 Ferrous metals, 36 Metals nec, 37 Metal products, 38 Motor vehicles and parts, 39 Transport equipment nec, 40 Electronic equipment, 41 Machinery and equipment nec, 42 Manufactures nec.
} 


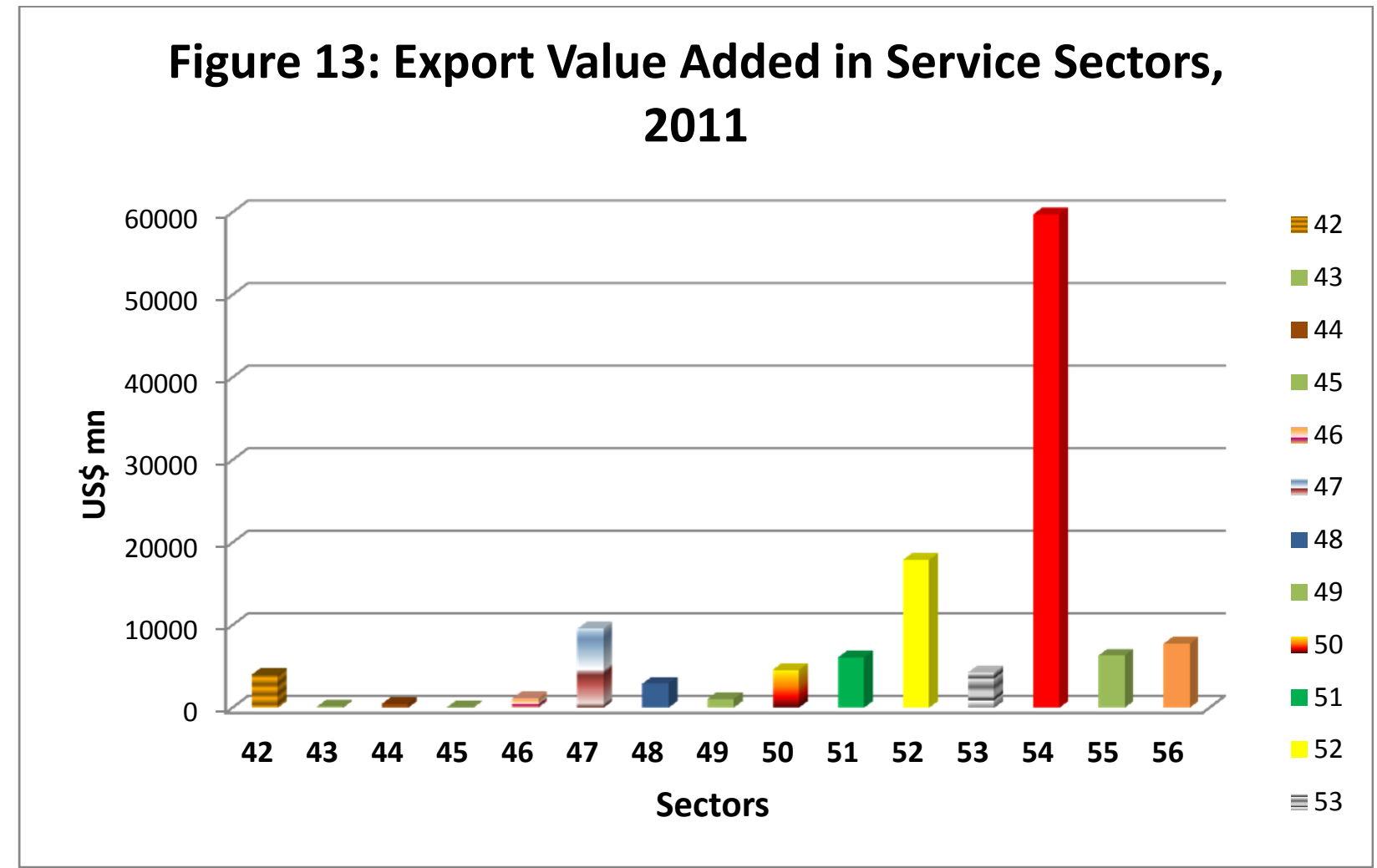

Note: Author calculation using Gtap 2011 data. Sector definitions in note to Figure 9

Figure 14: Export Value Added in Manufactures Sectors, 2011

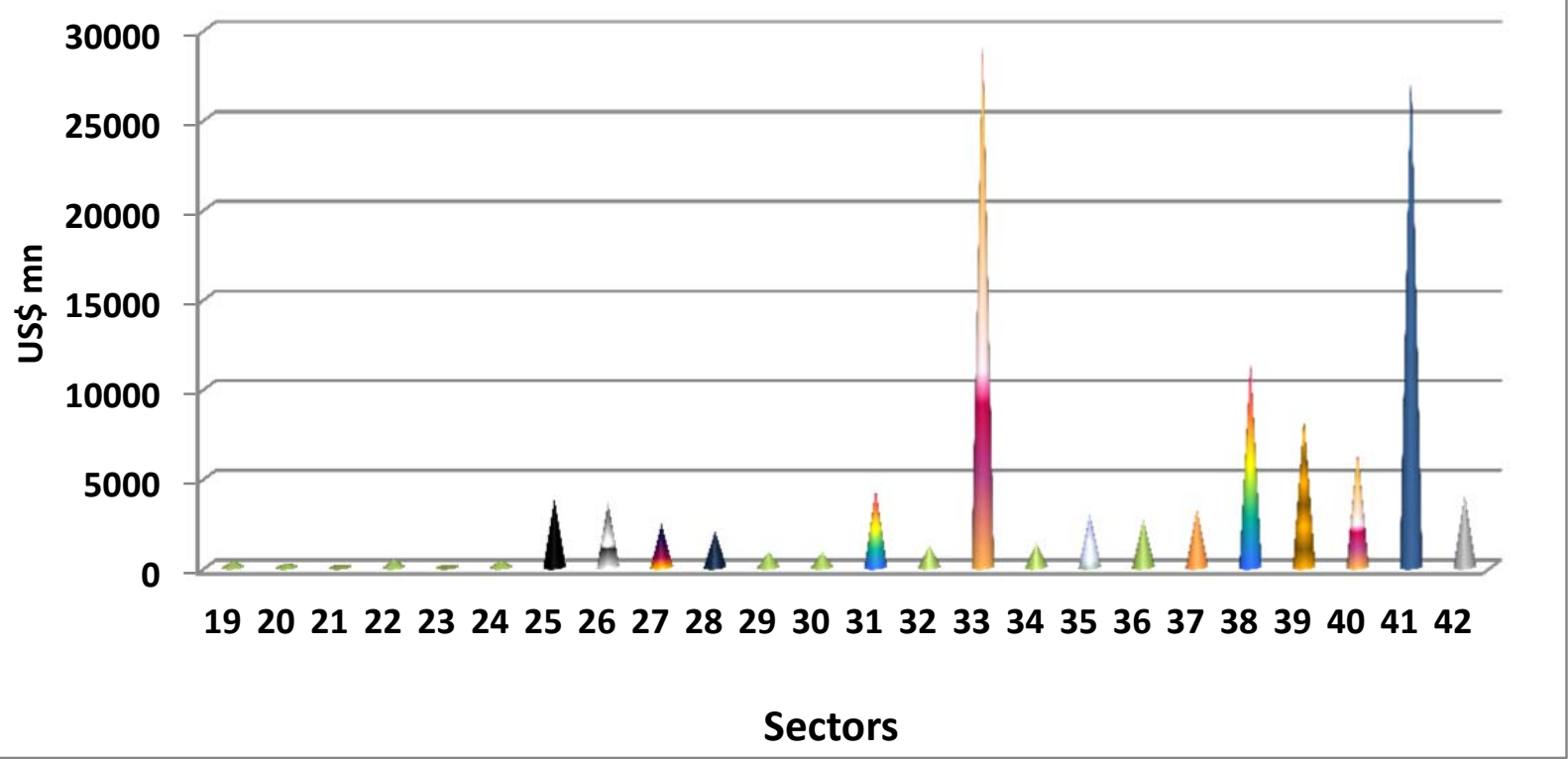

Note: Author calculation using Gtap 2011 data. Sector definitions in note to Figure 9. 
Figures on Historical Aggregate Tariff and 2011 Breakdown

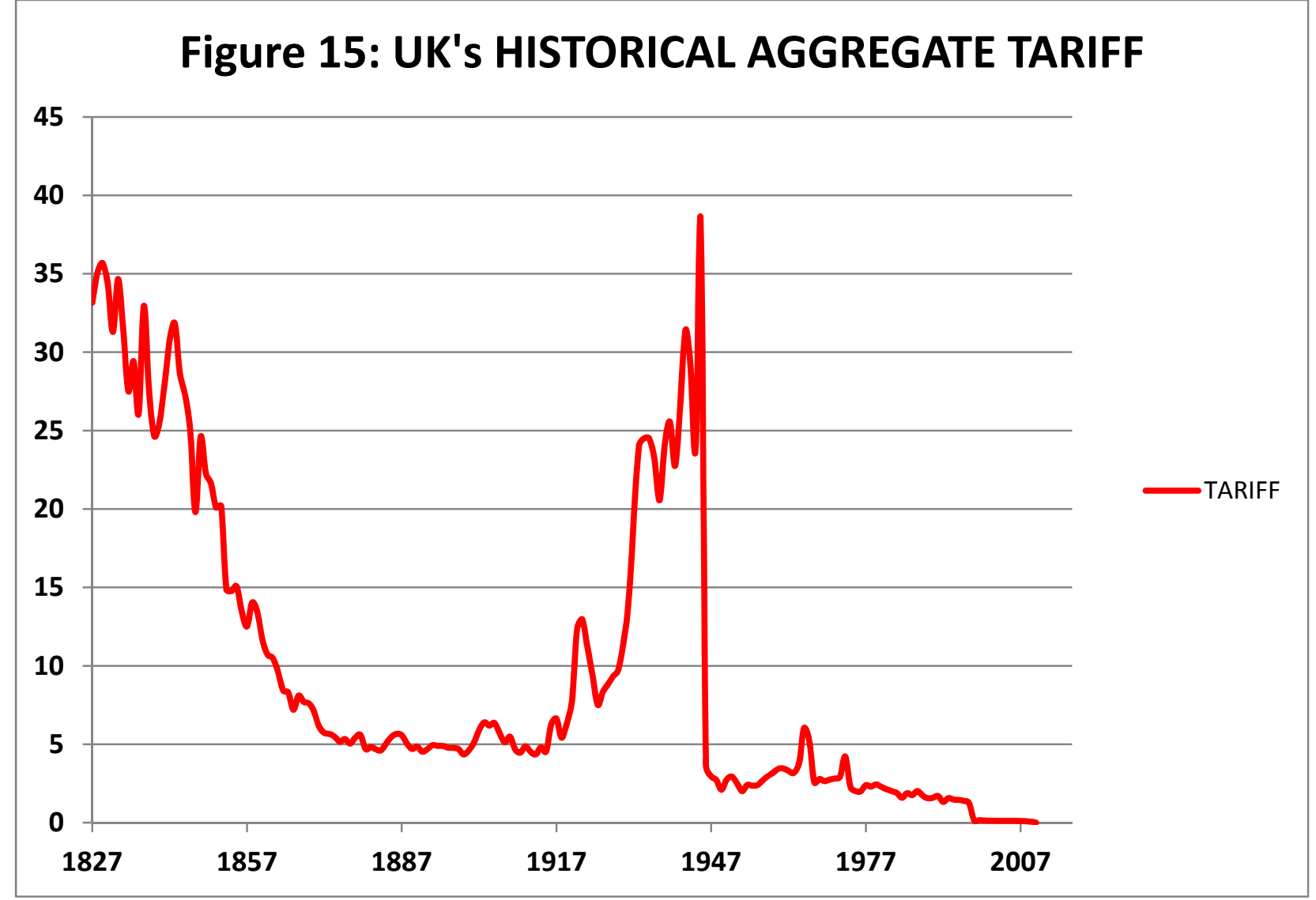

Note: Author calculation using CEPII data. 


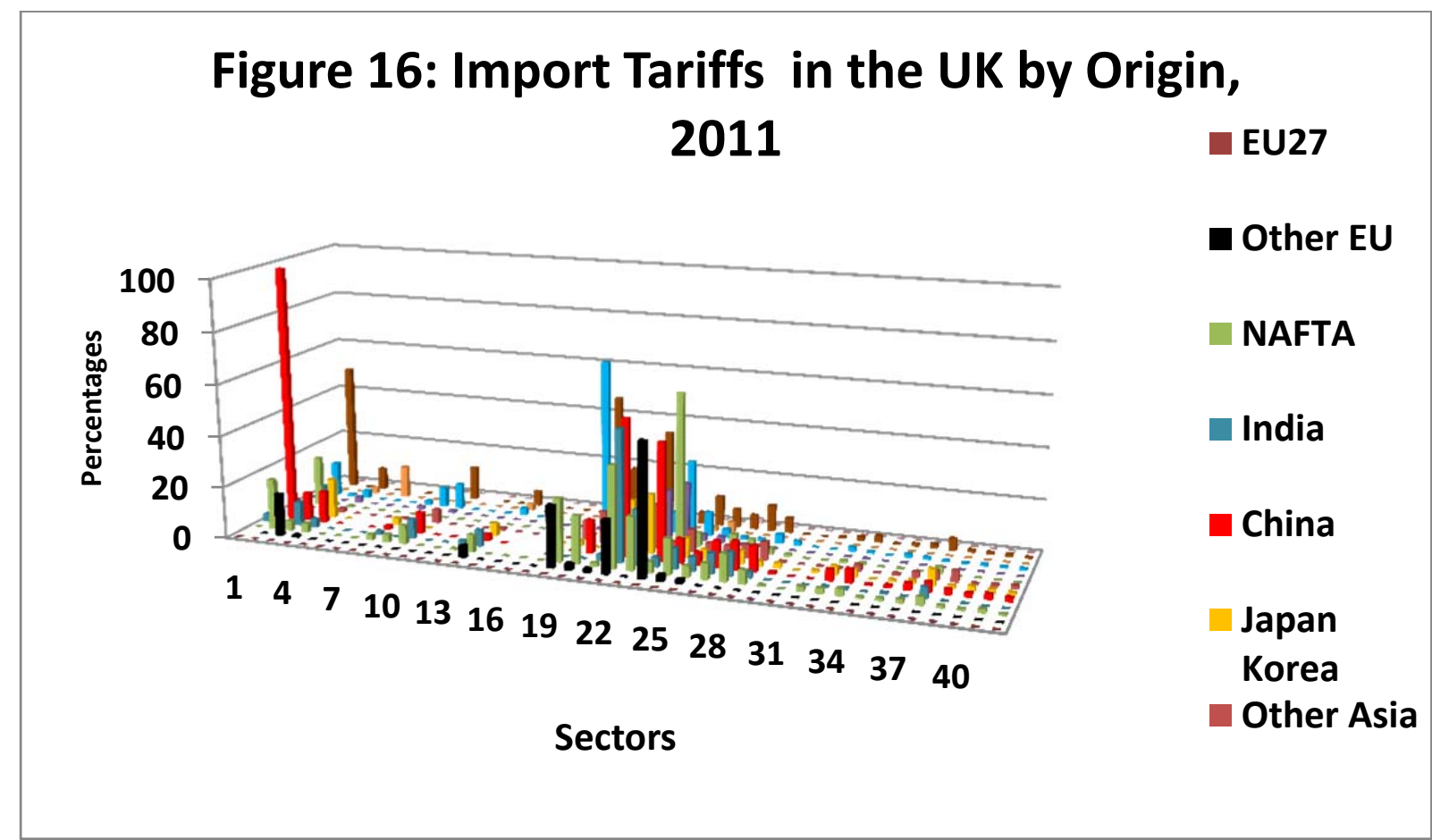

Note: Author calculation using Gtap 2011 data.

Figure 17: UK's Export Tariffs by Origin, 2011

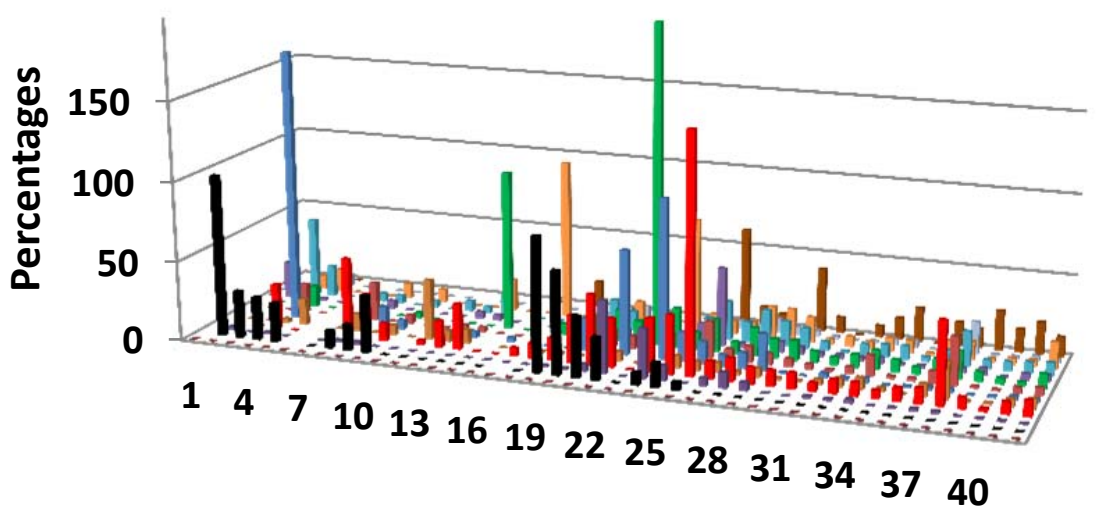

EU27

Sectors

- Other

EU

- NAFTA

- India

China

Japan

Korea

Other

Asia

Note: Author calculation using Gtap 2011 data. 


\section{Conclusions}

This briefing paper provides a summary of the research evidence together with basic institutional and factual information about the economic impact of changing the UK's trade arrangements after Brexit. The material here draws on and summarises some of the discussion at a conference, hosted at Loughborough University London, Stratford East, on Dec $9^{\text {th }} 2016$, which was financed by the ESRC through their UK in a changing Europe initiative.

While written by three active university researchers - who are therefore somewhat distant from the practicalities of business - our findings are remarkably similar to those reached recently by the Director General and Chief Economist of the Confederation of British Industry. In a speech at the London School of Economics, on $6^{\text {th }}$ July 2017 , they argued the case for an open-ended transitional deal that will keep the UK inside of the Single Market and of the European Customs Union, until new post-Brexit trade arrangements with the EU are in place. ${ }^{24}$

Alteration of UK trade arrangements is challenging. As in any exercise in economic policy analysis, there is plenty of room for disagreement. But disagreement should be a starting point for discussion, focusing on those assumptions - whether about the economic mechanisms of trade or the facts of trade - which lie behind these disagreements.

We find (Section 4, Table 5) that trade with the EU and with other countries in Europe who are closely economically integrated with the EU is the large majority of UK external trade. It accounts for $£ 452 \mathrm{bn}$ out of the total $£ 816 \mathrm{bn}$ of UK exports of goods and services in 2014 and £533bn out of the total £878bn of UK imports of goods and services in 2014. While the UK engages in substantial trade with other countries, notably our exports of goods and services to the US (around one half of all our non-European exports) it is clear that a priority in creating new trading arrangements for the UK must be preventing a large increase in tariff and especially non-tariff barriers for trade with Europe.

We discuss the institutional arrangements for UK trade and some of thechallenges of amending them (Section 3). This is a challenging and complex task involving multiple

\footnotetext{
${ }^{24}$ Fairburn, C., \& Newton-Smith, R. (2017). "Eyes wide open": the importance of a smooth transition to a new EU deal. CBI. Retrieved from http://www.cbi.org.uk/news/speech-eyes-wide-open-theimportance-of-a-smooth-transition-to-a-new-eu-deal/
} 
interest groups. There is no 'off the peg' solution, rather it is necessary to negotiate with the EU and with other trading partners new deep and comprehensive free trading arrangements, with explicit provisions for each sector of international trade in both goods and in services. Moreover there is a difficulty challenge of sequyencing. With the EU remaining our major trading partner we will be unlikely to make progress on deals with other countries outside the EU until EU trading arrangements have been largely agreed; discussion even with the EU will have to take into account the interests of manour discus different interest groups in the UK and in all the countries of the EU and so will themselves take years; and no detailed discussion with the EU can take place until after we have agreed our Article 50 terms of withdrawal. Moreover nothing is finally agreed until everything is agreed, including agreement in difficult areas such as agriculture and associated tariff quota agreements. Thus even EU trade deals will be a task of some years.

Finally we have reviewed the economics of trade and the varying estimates of different economists on the trade and economic impact of altering the UK's trading arrangements after Brexit. We show that the substantial variation of these estimates can be explained, almost entirely, by the assumptions made about non-tariff barriers to trade. The positive view of Economists for Brexit, with a long run increase in UK GDP of $4 \%$, is based on an underlying and unstated assump[tion that non-tariff barriers for trade with Europe do not increase post-Brexit, something that can be achieved, but only if we have a long transition period of exactly the kind proposed by the CBI. The other more negative projections are based on the assumption that nontariff barriers to trade with the EU rise, but provided we engage properly in negotiation of a tailored deep and comprehensive free trade agreement with the EU - a task that we think will take about five years once it begins - then these rises in barriers to trade can be avoided. In the meantime, to avoid high economic costs of Brexit, the UK will have to remain in the Single Market, and presumably therefore continue making contributions to the EU budget and accepting freedom of movement of labour.

Departure from the European Customs Union can likely take place much earlier, ahead of a full agreement on non-tariff barriers (standards and regulations) though this too will have to deal with tricky questions, for example the Northern Ireland/ Republic of Ireland border and the application of rules of origin once we reach agreement on replacement tariffs with the EU.

Both in theory and in practice the choices for future trade arrangements for the UK post-Brexit are clear, there is no sensible alternative to an extended transition arrangement that will last perhaps until 2024. 
The final decision though must of course be political and political decision making can result in a different outcome. We believe that the political choices are best framed as in two dimensions - cost and time - as set out in Figure 1 of our executive summary. A sensible political process would ensure that commitment to Brexit, respecting the outcome of the referendum - was accepted on all sides, and would therefore make politically possible the choice of a slow but managed Brexit. Regrettably though we may be about to endure a national tragedy, a plunge into a costly rapid Brexit because or political institutions are unable to support a longer term commitment.

We recall the phrase from Shakespeare's Othello: "To mourn a mischief that is past and gone is the next way to draw new mischief on." Both sides of the referendum debate seem to continue in election mode without ever actually listening to each other or addressing the practical challenge of actually implementing the referendum decision. ${ }^{25}$ It seems to us that the dysfunction of our political system may well make it impossible for the country to move on beyond the result of the referendum and the outcome will be the national tragedy of a rapid Brexit that, in line with the most pessimistic economic projections ("Project Fear") results in a decline of UK GDP in coming years of perhaps $5-8 \%$ (the range of impacts from various studies assuming no replacement of the single market through a deep and comprehensive free trade agreement between the UK and the EU).

\footnotetext{
${ }^{25}$ A troubling reminder took place at our conference of Dec 2016, when one of the final panellists, a well-known proponent of Leave arguments, made the mistake of talking over the audience, without recognising or acknowledging the very real concerns voiced earlier in the day about trade impact of those arguing for Remain. The consequent hostility and breakdown of communication jn the room was both palpable and disheartening. Both sides have valid arguments and must listen to each other.
} 


\section{Further reading}

There is a great deal to read on the trade implications of Brexit. We recommend in particular the following:

- The various briefing papers of the Sussex University based UK Trade Policy Observatory https://blogs.sussex.ac.uk/uktpo/

- The lucid arguments of Economists for Free Trade (formerly Economists for Brexit https://www.economistsforfreetrade.com/)

- Many excellent contributions at Vox-EU http://voxeu.org/taxonomy/term/5467

- The thoughtful work, from a pro-leave perspective, of the Legatum institute Special Trade Commission http://www.li.com/programmes/special-tradecommission

- The thorough and balanced assessment of the Confederation of British Industry http://www.cbi.org.uk/business-issues/brexit-and-eu-negotiations/

- The book by conference participant David Bailey:. Bailey \& L. Budd (Eds.), The Political Economy of Brexit. Agenda Publishing; especially the chapter Bailey, D., \& De Propris, L. (2017). What does Brexit mean for UK Automotive and Industrial Policy?

- Analysis by the Brussels think tank The European Centre for Political Economy http://ecipe.org/blog/tag/brexit/

Those with a taste for more technical analysis can follow the work of the London School of Economics Centre for Economic Performance, the Institute for Fiscal Studies and the National Institute of Economic and Social Research. 